\title{
Global Hunger, A DOUbling Population, AND ENVIRONMENTAL DEGRADATION: JUSTIFYING RADICAL CHANGES IN U.S. FARM POLICY
}

\begin{abstract}
Take some poor and unfruitful year in which hunger has carried off many thousands of men. If the barns of the rich were searched at the end of the year, I maintain that enough grain would be found to feed everyone, and to save those who died from the famine and from the plague caused by famine. How easily the bare needs of life might be provided, if money, which is 'meant to procure the necessities of life, did not deter us! Certainly rich men know this. They also know that it would be far more practicable to provide the necessities of life for everyone than to supply superfluities for a few, and much better to eradicate our innumerable evils than to be burdened with great concentrations of wealth. ${ }^{1}$
\end{abstract}

\section{INTRODUCTION}

Forget utopia. For the first three-quarters of the twentieth century an estimated twelve to fifteen million people died due to famine, and "many if not the majority were due to deliberate governmental policy, official mismanagement, or war, and not to serious crop failure." 2 Today, global hunger plagues nearly one billion people - almost one-fifth of the world's inhabitants. $^{3}$ It contributes to the deaths of an estimated 35,000 human

1. ThOMAS MORE, UtOPIA 81 (H. V. S. Ogden trans. \& ed., 1949). Thomas More, born in 1478, was educated at Oxford and became a barrister in 1497. He wrote Utopia in 1516, and reason, the law of nature, guides More's Utopians under Christian ethics within the context of a communal social system. More accepted an office on the King's Council in 1518, but King Henry VIII had him beheaded in 1535 for refusing an oath to the King as Supreme Head of the Church of England.

2. Dennis T. Avery, Saving the Planet With Pesticides and Plastic 146 (1995) (quoting D. Gale Johnson, World Food Problems And Prospects, Foreign Affairs Study No. 20, American Enterprise Institute (1975)).

3. Asbjorn Eide, Obstacles And Goals To Be Pursued, in ECONOMIC, Social AND Cultural Rights 381, 381 (Asbjorn Eide et al. eds., 1995). See The Hunger Web, available at Internet, http://www.hunger.brown.edu/hungerweb (defining hunger as the insufficient intake of food to provide the energy and nutrients essential for health, activity, and human development, and malnutrition as the outgrowth of hunger in which the body does not obtain a sufficient supply of the essential nutrients). See generally Elizabeth Rohrbaugh, Comment, On Our Way To Ten Billion Human Beings: A Comment on Sustainability and Population, 5 Colo. J. INT'L ENVTL. L. \& POL'Y 235, 236 (1994) (discussing limitations on global food, water, and energy resources and the population control mechanisms in China and India). See also UNICEF's State of the World's Children 1995 Report, available at Internet, 
beings every day, seventy-five percent of whom are children less than five years old. ${ }^{4}$ The problem is not production or overpopulation; it is poverty and accessibility. ${ }^{5}$ People in less developed countries (LDC's) either lack the access to adequate food supplies, or they simply cannot afford to grow or pay for their own food. ${ }^{6}$ The world's population, nonetheless, is expanding rapidly; hunger in developing countries tends to increase family size so that children can work to supplement food purchasing power. ${ }^{7}$ The United Nations projects that the world's population will reach nearly 8.5 billion in 2025 , and will exceed ten billion by $2050 .^{8}$ This could effectively endanger the food security of hundreds of millions of people. ${ }^{9}$ In the short term,

gopher:Ilhqfausor. unicef.org/11/.s495sowc (indicating that each year 13 million children die due to preventable diseases and malnutrition).

4. See The Hunger Project, available at Internet, http://www.igc.apc.org/thp/info bro.html\#challenge.

5. Id. See Gerard Piel, Worldwide Development or Population Explosion: Our Choice, CHALLENGE, July 17, 1995, at 13, available in WESTLAW, TRD \& IND database. See also IFAD Conference on Hunger and Poverty, An Overview, available at Internet, http:// www.unicc.org/ifad/over.html (discussing the history and nature of the problems of hunger and poverty).

6. Id. See Joel E. Cohen, Population Growth and Earth's Human Carrying Capacity, SCIENCE, July 21, 1995, at 341. In 1992, 15 percent of people in the world's richest countries enjoyed 79 percent of the income. In 1960 , the richest countries with 20 percent of the world's population earned 70.2 percent of global income, while the poorest countries with 20 percent of world population earned 2.3 percent of global income. The ratio of income per person between the top and bottom one-fifth of the population was 31:1 in 1960;32:1 in 1970; 45:1 in 1980; and 61:1 in 1991. This represents an ever widening gap from $\$ 1864$ per person in 1960 to $\$ 15,149$ in 1989 . Id. at $345 \mathrm{n} .7$ (citing the UNITED NATIONS DEVELOPMENT PROGRAMME, HUMAN DEVELOPMENT REPORT 1992).

7. Id. See The Hunger Web, Myths and Facts About Hunger, available at Internet, html://www.hunger.brown.edu/hungerweb/6_myths_and_facts.html.

8. Population Information Network (POPIN); Gopher of the United Nations, Population Division, Department for Economic and Social Information and Policy Analysis, available at Internet, gopher://gopher.undp.org/11/ ungophers/popin/icpd.

9. Food Security, PEOPLE \& THE PLANET (1995), available at Internet, http:// www.oneworld.org/patp/pap_foodsec.html. See Definitions of Food Security, available at The Hunger Web, supra note 3. The 1986 World Bank Policy Study on Poverty and Hunger defined Food Security as the access by all people at all times to enough food for an active, healthy life. Ensuring Food Security requires that adequate food supplies are available at all times through domestic production or imports and that the undernourished have the ability to acquire food, either because they produce it themselves or because they have the income to acquire it. See also Population: Growth, Arable Land Scarcity Threaten Food Security, Global Information Network, Apr. 10, 1995, available in WESTLAW PTS-NEWS database. (Population Action International (PAI) projects that China's population in 2025 will represent more than half of those who will be affected by global land scarcity; eight of 29 countries projected to be land-scarce in $\mathbf{2 0 2 5}$ are in Africa, with six other African countries approaching the benchmark for that rating. Of the 29 projected land-scarce countries, 12 will be waterscarce; they will have less than 1000 cubic meters of renewable fresh water per person per year to use for farming, industrial, and other household purposes.) 
foreign food aid needs are expected to almost double by $2005 ; 10$ "chronic and emergency grain food aid needs are estimated for sixty developing countries in Africa, Asia, and Latin America . . . [representing] about forty percent of the world's population," 11 amidst a trend in the United States of decreasing aid consistent with changing foreign policy objectives. ${ }^{12}$

Adding twice as many people to the planet, however, is not the only problem. The earth's carrying capacity will be limited in part by the strain on the environment. Whether the result of the growth in food production over the past half century, or "nation-by-nation food self-sufficiency," 13 there has been extensive resource depletion and exploitation. Destruction of tropical rainforests, erosion of the ozone, draining of wetlands, chemical residues and over fertilization, soil erosion, salt build-up from overirrigation, and expanding deserts all threaten the future of the world's food supply ${ }^{14}$ as well as fragile ecosystems and wild species through habitat destruction. ${ }^{15}$

In responding to the ever increasing demand for food, some propose going beyond what they believe are at least moral obligations contained in the International Covenant on Economic, Social and Cultural Rights (CESCR) to give the "right to food" a more effective means of addressing world famine. ${ }^{16}$ Unfortunately for many, neither present nor future relief for the hungry is likely to come from enforcing the corresponding duties of fundamental human rights in the United States. The barrier arguably stems from a fundamental disagreement in values between the United States and the

10. World Food Aid Needs and Availabilities, Economic Research Service, USDA Oct. 20, 1995, available at Internet, ll.edu:70/00/reports/erssor/international/gfa/world_food_aid_ 10.20 .95 .

11. Id.

12. David R. Lee \& Larry D. Sanders, U.S. Foreign Food Aid Policy, available at Internet, http://ianrwww.unl.edu/ farmbill/foodaid.htm (discussing the current situation of declining food aid assistance due to a declining commodity 'surplus' and donors preferring different forms of development assistance-U. S. Food aid from 1990-92 is significantly below that in the 1960's and 70's and the long term declining trend in U. S. Food aid commitments, budget constraints, and the focus on domestic over foreign areas of concern make additional food aid commitments in the 1995 farm bill unlikely). See Bard, infra note 19.

13. AVERY, supra note 2, at 321-22.

14. Norman W. Thorson, Presidential Address - Agriculture in the Twenty-First Century: The Perils of Population Growth in a Sustainable World, 25 U. MEM. L. REV. 863 (1995). See Resources, ENVIRONMENT, AND Population: PrESENT KNOWLEDGE, Future Options 408-21 (K. Davis \& M. S. Bernstam eds., 1991).

15. AVERY, supra note 2 , at 9.

16. See Robert Robertson, The Right To Food in International Law, in HUMAN RIGHTs in the Twenty-first Century: A Global Challenge 451, $451-57$ (Kathleen E. Mahoney and Paul Mahoney eds., 1993). 
international community. ${ }^{17}$ Although some would argue that the "right to food" exists as a legal and enforceable right in international law, ${ }^{18}$ the United States insists on using discretion to determine the level of contribution regarding international welfare requirements. ${ }^{19}$

In spite of the predictions of progressive famine,$^{20}$ there may actually be less hunger in the world than many people realize. ${ }^{21}$ Most hunger, concentrated primarily in Sub-Saharan Africa, ${ }^{22}$ can be attributed to disease, civil unrest, or war. ${ }^{23}$ Yet, some believe that "[t]he real opportunities for

17. Philip Alston, U.S. Ratification of the Covenant on Economic, Social, and Cultural Rights: The Need for an Entirely New Strategy, 84 AM. J. INT'L L. 365 (1990).

18. See Asbjorn Eide \& Allan Rosas, Economic, Social and Cultural Rights: A Universal Challenge, in ECONOMIC, SOCIAL AND CULTURAL RIGHTS 15 (Asbjorn Eide et al. eds., 1995).

19. See Robert L. Bard, The Right to Food, 70 IowA L. REV. 1279 (1985).

20. AVERY, supra note 2, at 19 . Lester Brown, a noted environmentalist of the Worldwatch Institute, has predicted that famine would occur on account of widespread population growth for the last 25 years. See Feeding a World of 8 Billion, PEOPLE \& THE PLANET, available at Internet, http://www.oneworld.org/patp/vol4_overview.html. (The FAO study, Agriculture: Toward 2010, indicates a rise in global food output of 1.8 percent a year over the next 20 years, outpacing an expected population growth of 1.7 to 1.3 percent per year, but the study also indicates that 650 million people will still not be adequately fed in 2010.)

21. AVERY, supra note 2, at 147.

22. Id. at 151-53.

23. Id. See Robert D. Kaplan, The Coming Anarchy, ATLANTIC Monthly, Feb. 1994. Tyranny is nothing new in Sierra Leone or in the rest of West Africa. But it is now part and parcel of an increasing lawlessness that is far more significant than any coup, rebel incursion, or episodic experiment in democracy .... The cities of West Africa at night are some of the unsafest places in the world. Streets are unlit; police often lack gasoline for their vehicles; armed burglars, carjackers, and muggers proliferate .... In Abidjan, effectively the capital of the ... Ivory Coast, restaurants have stick and gun-wielding guards . . . . After university students . . . caught bandits who had been plaguing their dorms, they executed them by hanging tires around their necks and setting the tires on fire .... I Ivorian policemen stood by and watched the "neck lacings" afraid to intervene . . . . Polygamy continues to thrive in sub-Saharan Africa $\ldots$ and loose family structures are largely responsible for the world's highest birth rates and the explosion of the HIV virus on the continent . . . . Disease, overpopulation, unprovoked crime, scarcity of resources, refugee migrations, the increasing erosion of nation-states and international borders, and the empowerment of private armies, security firms, and international drug cartels are now most tellingly demonstrated through a West African prism.

Id. Kaplan describes a slum district of Abidjan as

a checkerboard of corrugated zinc roofs and walls made of cardboard and black plastic wrap . . . ravaged by flooding . . . [where] few residents have access to electricity, a sewage system, or a clean water supply . . . . Children defecate in a stream filled with garbage and pigs, droning with malarial mosquitos. In this stream women do the washing.

Id. See also Situation in Sierra Leone Worsens, Oct. 10, 1995, UNICEF press release, available at Internet, http://www.oneworld.org/unicef/sierra_10oct.html (indicating that rebel 
feeding a world of eight billion in a sustainable and equitable way have been drowned by predictions of doom." ${ }^{24}$ In spite of the negativity, a future without famine can be realized, depending to a large extent upon the United States' leadership to further integrate agriculture into international trade. This integration would continue the capital market liberalization launched by the Uruguay Round of the General Agreement on Tariffs and Trade (GATT) by further eroding trade barriers and expanding opportunities for distribution to developing countries. ${ }^{25}$ More important, however, are the domestic policies that undergird international free trade and whether policy makers will continue the farm programs that remain largely unchanged since their inception more than sixty years ago. Without drastic change in policies that take large expanses of fertile U.S. cropland out of production while subsidizing farmers for not producing, restrict U.S. farmers to producing for the domestic market by pricing them out of the international marketplace, control market prices through government controlled surplus, utilize export subsidies to dump U.S. agricultural products on the world market, and encourage overuse of fertilizers and pesticides, the world will neither eliminate the hunger that exists nor can it expect to feed a doubling population with environmental stewardship. "We have the ability, as members of the human race; we have the means; we have the capacity to

attacks in Freetown-Bo-Kenema have resulted in serious shortages of food and widespread hunger and starvation leading to the deaths of an estimated 30 children per day. The number of "street children" in Kenema and Bo exceed 3000; some are only 4 years old).

24. Energy and Food for All, PEOPLE \& THE PLANET, available at Internet, http://www.oneworld.org/patp/vol4 newsfile.htm (quoting David Hall of King's College, London). See also Tim Dyson, Be Wary of the Gloom, PEOPLE \& THE PLANET, available at Internet, http://www.oneworld.org/patp/vol4_gloom.html. Dyson reviews several misunderstandings about current trends that have contributed to the "alarmist and overlypessimistic" views on the world's food production capacity noting that the main reason population has outpaced cereal production is that farmers in major grain-growing regions such as the United States and the European Union have had little incentive to cultivate cereals. In addition, large areas of cereal cropland have been idled or set aside.

[1]t seems inevitable that . . . most of the world's developing regions are going to become significantly more dependent upon supplies of cereals from outside. Their collective demand for imports will greatly increase, and it will be met by increased cereal production in North America, Europe, Australia, Argentina and ... perhaps Brazil. Most developing regions should be able to finance these imports.

Id.

25. Thomas J. Duesterberg, The Urgent Need to Finish Farm Trade Reform, HuDsoN Briefing PaPer, June 1995. See Foreclosing The Future, PEOPle \& THE Planet 32 (1995), available at Internet, http:/www.oneworld.org/ patp/ vol4 foreclosing.html. "We are at a crossroads. Humanity now has the analytical tools and basic knowledge to discern the consequences of continuing on its present course. We are headed in the direction of increasing vulnerability to various unpleasantries, such as famine, mass migration, disease, and warfare, and at the same time rapidly foreclosing many of our best options." Id. 
eliminate hunger from the face of the earth in our lifetime. We need only the will."26

\section{IN SEARCh OF A NEW PARAdigm FOR U.S. AgriculturE}

The international community's failure to solve the world hunger problem is evidenced by the twenty percent of the world's population who are either starving or malnourished and the many thousands who die each day. However, this note does not purport to resolve the dilemma concerning the moral or legal obligations associated with the concept of a right to food, nor does it judge current policies attempting to curtail the world's expanding population. Instead, it establishes as a background the reality of the doubling population, the opportunity for stabilization, and the economic and environmental forces impacting on whether ten billion people are within the limits of the earth's carrying capacity.

Specifically, this note addresses the major role that American agriculture must take to help reverse the environmental trends that will threaten food security worldwide and to ensure a future world without famine. ${ }^{27}$ Part II begins this background with some lessons from the past including an overview of population trends, economic development, food production, and distribution issues. It concludes with an overview of the global environmental degradation that has occurred indirectly, at least, because of U.S. agricultural policies, trade barriers, and the unprecedented high yield agriculture since the 1950's. Part III presents a brief discussion of the "right to food" to demonstrate the lack of any meaningful chance this notion has of changing the way the United States perceives world hunger and how it should be addressed-that is through industrialization and trade, rather than international development and food aid. This suggests the

26. Energy and Food for All, supra note 24 (quoting President John F. Kennedy).

27. See Forecasting The Future, PEOPLE \& THE PLANET, available at Internet, http//www.oneworld.org/patp/vol4_newsfile.html (highlighting the recommendations and findings from A 2020 Vision for Food, Agriculture and the Environment, a conference conducted by the International Food Policy Research Institute (IFPRI)). The IFPRI study indicates that "declines in investment in agriculture, combined with the overwhelming challenges of population growth, political unrest, urbanization, land degradation and water scarcity make the future uncertain." In addition, 10 million more children will be malnourished, developing countries will double their food imports and triple them in SubSaharan Africa. "Time is running out, already 1 billion people live on less than a dollar a day and 800 million people go to bed hungry. The 2020 vision will not be achieved unless the productivity of the poor is increased and their access to employment enhanced." Id. The study also indicates that two billion hectares of cropland, pastures, and forests have degraded over the last 50 years, most of which is reversible; however, some long-term damage has occurred. "Globally, about 18 percent of forest land, 21 percent of pastures and 37 percent of cropland is degraded." Id. 
interconnectedness of global hunger, global environmental issues, and global free-trade, where the interdependency of the interests of the United States and the Third World start to become apparent. Part IV turns to a discussion of the United States agricultural policy and outlines the basic programs that have continued for the past sixty years. It includes analysis of both recently proposed and subsequently enacted legislation and discusses how Congress is failing to effectively change the status quo in farm policy and the ramifications of its decision. Part V concludes with some suggestions and justifications for radical changes that would allow America's farmers to better compete in the world market. More importantly, it suggests that the United States government is at the threshold of a historic juncture-to determine whether the production demands and environmental challenges of the next half-century can be realized, and whether it has the political will to implement the kind of policy reform that will allow the market economy and market forces to dominate and foster equitable and efficient resource allocation and distribution.

\section{Population AND DeVelopment}

\section{A. Global Population and Development Trends}

In 1798, English economist Thomas R. Malthus hypothesized that "populations left unchecked by the natural constraints of limited food resources would progress geometrically, doubling approximately every twenty-five years. [However], [n]atural resource limitations meant that food production could increase only arithmetically; food production was therefore unable to keep up with rapid geometric population growth."28 World

28. Andrew D. Ringel, Note, The Population Policy Debate And The World Bank: Limits to Growth vs. Supply-Side Demographics, 6 GEO. INT'L ENVTL. L. REV. 213, 217 (1993). Malthus' hypothesis remains applicable as the "doubling time" for the world's population is decreasing steadily from 200 years in 1850 to 80 years in 1930 to 37 years today. This ideology, demonstrating that natural resources limit development, has become known as the "limits to growth" view. Id. at 214. The "limits to growth" view calls for active state intervention to control population increases (e.g., family planning measures). Id. at 220 . The contrary view is "supply-side demographics," based on the view that technology will allow for increases in food production to sustain more people. Id. In addition, the history of world development demonstrates that technological advancement increases the standard of living and results in population stabilization (e.g., large families declined as people became a less important resource and social security provided for the elderly and the disadvantaged). Id. at 221. But see Piel, supra note 5 (arguing that Malthus' view does not characterize world trends in population and development over the last 200 years). The "limits to growth" view has been adopted by the United Nations and the World Bank because they argue that economic development and technological advances will not stabilize population fast enough without other population control measures. Ringel, supra note 28, at 224. The United Nations Fund for Population Activities (UNFPA) was established in 1969 to help developing nations with 
population has increased from one billion in 1800 to 2.5 billion in $1950,{ }^{29}$ to $5,787,279,608$ as of September 8,1996 , now adding almost three people every second. ${ }^{30}$ The world fertility rate is currently 3.1. ${ }^{31}$ North America has reached stability (replacement level) at a fertility rate of 2.1.32 European countries range from 1.5 to 1.8; Africa from 4.2 to 6.5; Asia from 1.9 to 4.4; and Latin America from 2.8 to $3.5 .{ }^{33}$ On average, the fertility rate of the least developed countries is 5.8; less developed countries 3.5; and developed countries $1.7,{ }^{34}$ meaning that projected growth in the world's population over the next century will occur primarily in Africa, Asia, and Latin America-in the world's less or least developed countries. ${ }^{35}$ The World Bank has predicted twelve to nineteen billion people by $2100,{ }^{36}$ but this figure may be overstated. ${ }^{37}$ Nonetheless, despite some disagreement with specific numbers, even the most optimistic agree that population momentum dictates at least one more doubling of the world's population before any stabilization can occur. ${ }^{38}$

population and environmental strategies. Id. The Reagan-Bush Administration implemented the supply-side demographics model because it was consistent with their limited government intervention (laissez-faire ideology) and their pro-life position on abortion. Id. at 227 . In 1984 , the Reagan-Bush Administration cut funding ( $\$ 36$ million) to the UNFPA because of forced abortions in China. In 1994, the Clinton Administration renewed United States support to the UNFPA, and Congress included $\$ 50$ million in the Foreign Operations Appropriations Act of 1994. Rohrbaugh, supra note 3, at 241-42. See also Tim Stafford, The Bet, Understanding Population and Population Control; Are People the Problem? CHRISTIANITY TODAY, Oct. 3, 1994, at 46 . Congress designated $\$ 392$ million for population policies in the 1994 budget - an all-time high. Id.

29. John Bongaarts, Population Policy Options in the Developing World, SCIENCE, Feb. 11,1994 , at 771 .

30. World POPClock, U.S. Bureau of the Census, available at Internet, http://www. census.gov/ipc-bin /popclockw (projected to 9/8/96 at 6:09:37 PM EDT).

31. Births and age-specific fertility rates for major areas and regions of the world from 1990-1995 can be found in Population Information Network, supra note 8.

32. Id.

33. Id.

34. Id.

35. World POPClock, supra note 30. The population of the developing world alone is expected to grow from 4.1 billion in 1990 to 8.6 billion in 2050 and 10.2 billion in 2100 . Africa is expected to increase by five times from 0.6 billion in 1990 to 2.8 billion in 2100 .

36. AVERY, supra note 2, at 50-60.

37. Id. In one generation, the total fertility rates in the least developed countries have come within 30 percent of stability, dropping from 6.1 in 1965 to 3.4 in low-income countries and 3.0 in middle-income countries. Id. WORLD BANK, WORLD DEVELOPMENT REPORT 1994, 212-13 (1995). See Bongaarts, supra note 29 . Family planning programs in the developing world has increased contraceptive usage from 10 percent in the mid-1960's to 50 percent today. In East Asia, contraceptive use is now at 75 percent. Id.

38. See Bongaarts, supra note 29 . Population momentum is the tendency of the population size to increase for a period of time after the fertility rate reaches long-term stability as a result of a young population age structure and decline in mortality rates. Age 
Even with continued implementation of the "limits to growth" ideology, ${ }^{39}$ the world is fast approaching ten billion people, and some would suggest that in order to stabilize the world's population, the industrial revolution must expand worldwide. ${ }^{40}$ For example, China's gross domestic product quadrupled from 1977 to 1993, and per capita income has doubled since $1980 .^{41}$ In 1949 , ninety percent of China's people were illiterate; today seventy-five percent are literate, and their fertility rate approaches stability. ${ }^{42}$ "India's industrial output has been growing three times as fast as its population for a decade," ${ }^{43}$ and with the development of this industrial infrastructure, India has become the world's twelfth largest economy. ${ }^{44}$ India's fertility rate is now halfway to stability at 4.0.45 Indonesia's economic growth is eight to nine percent annually, and the poverty level is below fifteen percent, down from sixty percent in $1970 ; 6$ its fertility rate is also in decline. "Today, billions of Third World people are achieving new buying power more rapidly than any large group of people has before in history," 47 and their population growth rate has fallen from a high of 2.5 percent to 1.6 percent. ${ }^{48}$ Ethiopia is predicted to be the last major country

structure adjustment takes several decades to accomplish at which point population growth ceases. See also Steven Budiansky, 10 Billion For Dinner, Please; Technology and Free Trade Can Feed More People Than Many Believe Possible, U.S. NEWS \& WORLD REP., Sept. 12, 1994.

39. See Ringel, supra note 28. See also Bongaarts, supra note 29 (indicating that an estimated four to five billion dollars is being spent annually on population control programs in Africa, Asia, and Latin America).

40. See Piel, supra note 5. "We can reach zero-growth population, if we expand the world economy fourfold and share the proceeds equitably." Id. Piel points out that the industrial revolution brings on a demographic revolution or transition that proceeds through two phases: (1) the death rate in an industrializing country falls, and the population increases at rates measured by the difference between its birth and death rates; followed by (2) the decline in birth rates whereby the population approaches zero-growth. See, e.g., The Pacific Rim's Population Implosion, MARKET ASIA PAC., July 1, 1995 (illustrating that the AsiaPacific Region is rapidly progressing to a low-growth consumer oriented market like that of Europe and North America).

41. AVERY, supra note 2, at 54.

42. Piel, supra note 5, at 22. Piel notes that although China's lowering fertility is often attributed to their coercive population control policies ("one-child family"), recent attention has credited economic development for cultural changes in reproduction practices.

43. AVERY, supra note 2 , at 54.

44. Piel, supra note 5 , at 23.

45. Id.

46. Id.

47. U. S. Farm Policy in a Real World Context, Hudson Policy BUlletiN, Mar. 8, 1995 (excerpts from testimony by Dennis T. Avery, Director of the Center for Global Food Issues, Hudson Institute, before the Senate Agriculture Committee hearings on the 1995 Farm Bill, Mar. 9, 1995).

48. AVERY, supra note 2, at 51. 
to reach stability in $2050 . .^{49}$ This has encouraged some experts to predict that as the Third World gains affluence, the world's population will peak at around nine billion by 2040 and gradually decline thereafter. ${ }^{50}$ If this prediction is correct, the world has a fighting chance to feed this many people if it continues to expand industrialization, invest in biotechnology research, and provide the economic incentives to grow more food. ${ }^{51}$

\section{B. Global Food Production and Distribution}

The Food and Agriculture Organization (FAO) of the United Nations (UN) reports a decline in global food output and a significant depletion of world surplus. $^{52}$ Drought and floods in China have resulted in that

\section{Id.}

50. Id. at 57.

51. See Budiansky, supra note 38, at 59. "The world has not reached, nor is it near the upper limits of its capacity." (quoting B.H. Robinson of the U.S. Department of Agriculture). See AVERY, supra note 2, at 12 (noting that "we can feed, house, and clothe 10 billion people on less land than we use for farming and forestry today if we ... pursue yield-enhancing agricultural and forestry research . . . [and] [u]se the best and safest land to produce our field and tree crops"). See also Ian Carruthers, Trader's Fate; Global Food Distribution, NEW STATESMAN \& SoC'Y, Sept. 22, 1995 (arguing that: "[i]f the world is going to be fed, then traditional global trade flows must be reversed, ... . [and that] [c]ities in developing countries will largely be fed with food from temperate countries and pay for it by exporting manufactured goods and services traditionally produced in the north").

52. Annual Review-FAO of UN, World Food Situation, World Food Security Threatened by Decreasing Supplies, available at Internet, http://www.fao.org. Food staples were nearly 4 percent below 1992 levels, due to the decreased maize output in the United States. World cereal production was 5 percent below 1992, while wheat made a marginal gain due to near record harvests in Asia. Production of coarse grains fell almost 9 percent below 1992 levels, and rice production declined 1.4 percent. Production of root sand tubers increased by 2 percent; most of the growth occurred in the developing countries of Africa and Latin America, while production fell in China and India. Pulses, an important high protein staple, was up 4 percent due to near record production in Asia. Global production of milk declined 1 percent, but developing countries increased their production, and world meat production grew by only 1 percent, despite a decline in Africa. Production of fats and oils grew 2 percent due to large increases in soybean harvests in Brazil, groundnut crops in India, and palm oil output in Indonesia and Malaysia. After 1994, a 19 percent decline is expected in the global cereal surplus in developed countries, with a significant decrease in the surplus of maize, while wheat and rice carryover stocks also decline. World rice stocks are expected to reduce by 15 percent, marking the third year of decline. Global per capita food consumption in 1993-94 remained the same as 1992-93, but meat consumption declined for the first time since 1982, due primarily to economic conditions in Eastern Europe and the former USSR. Actually, meat consumption increased in most developing countries except Africa. Food aid to developing countries decreased almost 23 percent in 1993-94; cereal food aid to Low-Income Food-Deficit (LIFD) countries (primarily in Sub-Saharan Africa) were down almost one-third from 1992 93. The decline in world food security has affected many developing countries, and Africa's food situation remains threatened. See Rose Umoren, Africa Agriculture: Africa's Food Situation Remains Precarious, May 17, 1995, available in WESTLAW PTS-NEWS-C 
government's use of rationing coupons. ${ }^{53}$ From 1976 to 1992 , Latin America, despite increasing areas of food production and technology, lost 0.3 percent per year in per capita grain production, while per capita consumption grew by 0.5 percent; Africa also lost 1.4 percent annually over that same time period. ${ }^{54}$ In Asia, consumption is outpacing production while population increases and industrialization continue to reduce available farmland. ${ }^{55}$ Yet, as these economies continue to grow, better diets should be affordable. ${ }^{56}$ The global demand for farm resources is projected to rise by thirty to fifty percent during the 1990's. ${ }^{57}$

While agricultural productivity may have peaked for some grains in some regions, it is still increasing in others. Asian production of rice, which provides thirty percent of total caloric intake in developing countries, has leveled since the 1980's and has been reduced to 1970-74 levels in Latin America. ${ }^{58}$ In contrast, wheat production in Asia has increased nearly three

database.

53. See Grain Shortages Bring Back Rationing to China, ASIAN ECON. NEWS, June 5, 1995, available in WESTLAW PTS-NEWS-C database. Ration coupons allow for grain purchase at subsidized rates because of supply and demand problems. Since 1953 China's government has bought grain from its farmers and sold it to those in urban areas at heavily subsidized rates. This allowed the government to keep wages low and was a catalyst for industrialization, but it reduced the growth of agricultural output. Farmland is being reduced by factories, housing, golf courses, and roads, leading to a loss of nearly one million hectares of farmland each year. Farmers are also migrating to urban areas because they cannot earn an adequate income with grain prices staying at low levels. Analysts project that China will become the world's largest importer of grain due to severe shortages. Estimates indicate that by 2030 China could be importing 350 million tons of grain-that equals the total supply on the international market in 1993. Id.

54. Thomas J. Duesterberg, The Urgent Need to Finish Farm Trade Reform, HuDSON BRIEFING PAPER, June 1995.

55. Id. See Lester Brown, Running Out of Loaves and Fishes; Global Resources, THE HUMANIST, Nov. 1994, at 30 (densely populated countries that continue to industrialize lose grain land to other uses; Japan has lost 52 percent of its grain land; South Korea 42 percent; and Taiwan 35 percent).

56. Id. See Thomas J. Duesterberg, The Coming Boom in American Agriculture, Hudson BRIEFING PAPER, May 1994, at 3. East Asia's economy now equals that of the United States and is growing rapidly; China's growth rate for 1994 was predicted to be 9.4 percent; South Korea's was 7.6 percent; Malaysia's was 7.5 percent; India's was 4.5 percent; Thailand's was 8.4 percent; and Indonesia's was 6.4 percent. Latin American countries also continue to show rapid growth in their economies; Mexico was expected to grow by 3.5 percent in 1994; Colombia by 4.4 percent; Chile by 6 percent; and Argentina by 5 percent. Id. at 4.

57. New Farm Technology: Conquering World Famine, AGRA EUR., July 26, 1991, available in WESTLAW PTS-PROMT database (citing Dennis Avery, Global Food Progress Report 1991, Hudson Institute) (half of the demand is expected for products used to upgrade diets such as meat, fruits and vegetables, and cooking oils).

58. Burgeoning Population Requires New Agenda, FERTILIZER INT'L, Mar. 1995. 
percent per year over the last twenty years, ${ }^{59}$ and maize yields are increasing at nearly the same rate. ${ }^{60}$ The experts have had mixed reactions with some predicting that the world's population will surpass the earth's "carrying capacity." 61 Today, food production in seventy-five developing countries does not keep pace with their expanding populations. ${ }^{62}$ Fifteen of these countries have had a twenty percent decline in per capita food production. ${ }^{63}$ Others predict, that despite the slow growth since 1990, total grain production will stay ahead of population expansion as evidenced by the steady drop in the world price of food over the last fifty years. ${ }^{64}$

\section{Food Production v. The Global Environment}

From 1950 to 1984 , world grain production expanded by a factor of 2.6 and outpaced population growth thereby increasing the grain harvested per person by forty percent. ${ }^{65}$ Oceanic food supplies increased by a factor of 4.6 from 1950 to 1989 , which doubled the seafood consumption per person. ${ }^{66}$ From 1984 to 1993 , however, grain production grew at only 1 percent annually, resulting in a twelve percent drop in grain production per person. ${ }^{67}$ The 1993 per capita seafood supply fell to nine percent below that level in 1988, and the FAO reports that "seventeen major oceanic fisheries are all now being fished at or beyond capacity and that nine others are in a state of decline." 68 This record of high production, "green revolution" 69 farming, and aggressive fishing has yielded environmental casualties that

59. Id.

60. Id.

61. See Budiansky, supra note 38 , at 58 .

62. Brown, supra note 55 , at 30 .

63. Id.

64. Budiansky, supra note 38, at 59. See AVERY, supra note 2, at 151-55. Per capita food production continues to gain except in Africa, particularly in Sub-Saharan Africa, where hunger remains a serious concern. However, Africa has only seven percent of the world's population, and nearly all of the recent famine there is directly related to civil strife and "shooting wars," whereas Asia, containing 75 percent of the world's population, has had much success in food production increases over the last 15 years. See also Cheryl Christensen \& Charles Hanrahan, Comment, African Food Crises: Short-, Medium-, and Long-Term Responses, 70 IOWA L. REv. 1293, 1293 (1985).

65. See Brown, supra note 55, at 30.

66. Id.

67. Id.

68. Id.

69. The "Green Revolution" commonly refers to the increased agricultural production (since the 1960's) in developing countries due to increased crop yielding varieties (as a result of biotechnology) and modern farming techniques, including the use of pesticides, herbicides, and irrigation. See also Robert L. Paarlberg, The Politics of Agricultural Resource Abuse, ENV'T, Oct. 1994, at 6 (discussing alternative explanations for environmental degradation). 
have become the focus of world environmental groups, including species extinction, soil erosion, rain forest depletion (deforestation), overgrazing, aquifer depletion from irrigation, destruction of wildlife habitat, expanding deserts (desertification), waterlogging and salt build-up (salination) from over irrigation, and the potential ill-effects of herbicide and pesticide use on water resources. All of these are not only major environmental concerns, but also factors that could endanger food security and the future of world food production. ${ }^{70}$ The World Resources Institute has reported that almost 500 million acres of trees have been cut down since 1970, and primarily because of this destruction, deserts have expanded by some 300 million acres. ${ }^{71}$ "Slash and burn agriculture," practiced primarily in Asia, Latin America, and Africa, contributes to a depletion of almost one percent of the total tropical area of rain forests each year. Because rain forests, the world's lungs, remove carbon dioxide from and return billions of gallons of water to the atmosphere, deforestation may contribute to global warming and risk the world's fresh water supply. ${ }^{72}$ Moreover, rain forests supply more than twenty-five percent of the prescription drugs available in the United States and are home to the world's largest reserve of plant and animal species. ${ }^{73}$ Yet ecosystems continue to be destroyed. "Third World residents are cutting trees 'nobody owns' because they have no jobs and need free fuel and free cropland." 74 The incentive to exploit these natural resources demonstrates the "tragedy of the commons" 75 in many Third World countries while the United States and Argentina continue to divert enough good cropland to feed an additional 1.5 billion people. ${ }^{76}$ The UN is addressing these issues at the

70. See Brown, supra note 55, at 30. See also John Skow, The Land: Less Milk and Honey? As Population Growth Puts Pressure on Forests and Fields, Producing Food for Ten Billion Could Be a Nightmare. TIME INT'L, Oct. 30, 1995, available at Internet, http://pathfinder.com/@@8nml7wgxzaaqmri/time /international/1995/951030/envi, and in WESTLAW TIME-LIFE database. See also Thomas M. Landy, Connecting Poverty and Sustainability, 21 B.C. ENVTL. AFF. L. REv. 277 (1994) (discussing how population expansion in Brazil affects global sustainability).

71. The HungerWeb: Hunger and the Environment, Relationships between the Hunger and Enviranmental Crises, available at Internet, http://www.hunger.brown.edu/hunger web/enviro.html. But see Soil Erosion Estimates and Costs, SCIENCE, July 28, 1995, at 461 (demonstrating the unreliability of recent global erosion estimates as determined by the Worldwatch Institute in State of the World 1984).

72. Jose O. Castaneda, Debt For Nature Swaps: An Increasingly Attractive Solution To A Pressing Global Problem, 2 PACE INT'L L. REv. 135, 136-37 (1990).

73. Id.

74. AVERY, supra note 2, at 310.

75. Id. at 316.

76. See AVERY, supra note 2, at 159-60. 
international level, ${ }^{n}$ but pressure in the United States comes from environmental groups urging tighter legislation regarding farm chemicals ${ }^{78}$ and fertilizers, as well as the pursuit of environment-friendly "sustainable" agriculture. ${ }^{79}$

Without farm chemicals, estimates indicate that world food production would be reduced by forty percent and food costs would rise by seventy percent. ${ }^{80}$ In the United States, "soybean yields would drop by 37 percent, wheat by 38 percent, cotton by 62 percent, rice by 63 percent, peanuts by 78 percent, and field corn by 53 percent." 81 Most important, without chemistry, "[w]e would need the land area of both South and North America (15-16 million square miles) to produce today's food supply, . . . [and in order to feed the projected population in 2050,] we should expect to plow down another 30 to 40 million square miles of wildlife for food production. That is the equivalent of South America, North America, Europe, and much of Asia." 82

77. See William C. Burns, The International Convention to Combat Desertification: Drawing a Line in the Sand, 16 MICH. J. INT'L L. 831 (1995). See also Agenda 21, adopted by the U.N. Conference on Environment and Development (UNCED) ("Earth Summit”) at Rio de Janeiro, June 13, 1992. U.N. Doc. A/CONF.151/26 (vols. I, II, \& III, 1992). The Earth Summit yielded an 800-page document (Agenda 21), focusing on environmentally sustainable development through the year 2000 and beyond. Agenda 21 represents the culmination of 178 nations at the conference recognizing that agriculture has a most vital role in meeting the growing population's food demands while protecting the earth's renewable resources.

78. John Carlucci, Reforming the Law on Pesticides, 14 VA. ENVTL. L. J. 189 (1994).

79. James Steven Carpenter, Farm Chemicals, Soil Erosion, and Sustainable Agriculture, 13 STAN. ENVTL. L. J. 190 (1994). See Jonathan Tolman, Poisonous Runoff From Farm Subsidies, WALl ST. J., Sept. 8, 1995, at 7. See also Karen R. Hansen, Agricultural Nonpoint Source Pollution. The Need for an American Farm Policy Based on an Integrated Systems Approach Recoupled to Ecological Stewardship, 15 HAMLINE J. PUB. L. \& PoL'Y 303 (1994). But see Bob Holmes, Can Sustainable Farming Win the Battle of the Bottom Line?, SCIENCE, July 25, 1993, at 1893 (discussing regional differences and other factors in determining whether sustainable agriculture can be economically and environmentally profitable).

80. Protection of Crops and the Environment Linked, ECO-LOG WEEK, Apr. 21, 1995, available in WESTLAW PTS-NEWS database. (The Crop Protection Institute reports that less pesticides are being used and that they are less toxic, target-specific (attacking the most vuinerable part of any weed, insect, or fungus) and that many are biodegradable within two weeks of application.)

81. AVERY, supra note 2, at 31 (citing E.G. Smith et al., Impacts of Chemical Use Reduction on Crop Yields and Costs, Agricultural and Food Policy Center, Dept. of Agricultural Economics, Texas A\&M University, in cooperation with the National Fertilizer and Environmental Research Center of the Tennessee Valley Authority, College Station, TX (undated)).

82. AVERY, supra note 2, at 31. 
Further data suggests that the dangers of pesticide usage are vastly overstated ${ }^{83}$ that chemical residues in foods pose an extremely low risk to health, and that most of the bad publicity concerning pesticides is nothing other than "scare tactics." 84 This data favors continued pesticide usage; moreover, because of low yields, sustainable agriculture (organic farming) cannot feed the world (requiring much more land to meet demand). ${ }^{85}$ Sustainable agriculture also suffers a much higher rate of soil erosion ${ }^{86}$ and limits income due to substantially higher labor and management costs. ${ }^{87}$ These factors, in addition to farm subsidies that encourage high pesticide and fertilizer use to maximize yields on less ground, provide a disincentive to farmers to either revert to organic methods or reduce their usage of chemicals. ${ }^{88}$

The real threat is not that the earth will run out of land, topsoil or water but that nations will fail to pursue the economic, trade and research policies that can increase the production of food, limit environmental damage and ensure that resources can reach the people who need them. Indeed, embracing the

83. Id. at 79. "[W]e consume only one ten-thousandth as much cancer risk in the form of pesticide residues as we do in the form of natural carcinogens in our food, . . . [and] [ $]$ ess than 3 percent of all cancer deaths are caused by all the combined forms of environmental contamination and pollution." Id. at 72-73. See IFIC Review: On Pesticides and Food Safety, International Food Information Council (IFIC), available at http://ificinfo.health.org/irpest.htm. The plentiful and affordable food supplies have contributed to the longevity of Americans who now live some 20 years longer than in the early 1900's. The National Academy of Sciences has reported that this improvement is partly attributable to the use of pesticides that have increased crop yields and made more fruits and vegetables available yearround. In addition, the American Medical Association claims that there is no scientific evidence linking the proper application of pesticides and adverse health effects in humans. More than 99.99 percent of the pesticides that Americans consume are natural toxins which are present in all plants including such foods as beans, lettuce, apple juice, wine, spinach, peanut butter, and others. Americans consume 10,000 times as much by weight of natural pesticides than they do of man-made chemical residues. Id.

84. AVERY, supra note 2 , at 82.

85. Id. at 167.

86. Id. at 174 .

87. Id. at 179 .

88. Id. at 360 . U.S. farm policies that set aside cropland and paid high price supports encouraged farmers to seek additional land and higher yields. Farmers proceeded to use fertilizers and pesticides to increase yields instead of rotating crops which is a very effective way to reduce pests and weeds. Part of the land sought out by farmers due to these policies were wetlands. (The government also paid farmers for acres taken out of production). Since 1955, U.S. farmers have acquired 15 million acres of wetlands, thus reducing wildlife habitat and causing the severe erosion of these marginal agricultural soils. Id. See also PAUL FAETH, Growing Green: Enhancing the ECONOMiC and Environmental Performance of U.S. AGRICULTURE, 24 (World Resources Institute 1995). Farm supports add to soil erosion, overuse of chemicals and loss of wildlife habitat " $[\mathrm{b}] \mathrm{y}$ raising the payments farmers receive for their crops but restricting the acreage they can plant, policies encourage intensive cropping and input use on the land that was planted." Id. 
myth of environmental scarcity could ironically prompt the United States and other countries to adopt policies that virtually guarantee that the apocalyptic future that environmentalists foretell really does come true. ${ }^{89}$

Regardless of what may be the problem, "[t]he persistence of hunger increases population growth, as parents strive to guarantee the survival of their children ... . [and] the world has come to recognize that hunger, the environment and population growth are inextricably linked in one common agenda for a sustainable future." 90 Arguably:

[m]ankind is at the most critical moment in environmental history. What we do as people and societies in the next decade will determine whether we have a more crowded but sustainable world to bequeath to future generations - or whether we will bring on the very apocalypse of famine and wildlife destruction that the gloomiest environmentalists have envisioned. Our decisions on agriculture and forestry will be the most crucial of all, because they will govern how we use two-thirds of the earth's surface. They will dictate the habitat - or loss of habitat - for [ninety-five] percent of the earth's wildlife species. ${ }^{91}$

\section{UNIVERSAL HUMAN RIGHTS}

\section{A. The Right to Food}

Human rights, including the "freedom from want,"92 became an international concern for the whole world when President Franklin D. Roosevelt delivered his "Four Freedoms" address in 1941. ${ }^{93}$ That impetus allowed for the creation of the United Nations in $1945,{ }^{94}$ and the General Assembly's adoption of the Universal Declaration of Human Rights (UDHR)

89. Budiansky, supra note 38, at 58. See E. F. Roots, Population, "Carrying Capacity," and Environmental Processes, in HUMAN RIGHTS IN THE TWENTY-FIRST Century: A Global Challenge 529 (Kathleen E. Mahoney \& Paul Mahoney eds., 1993).

90. The Mission of the Congressional Hunger Center, available at Internet, http://www. fh.org/chc/Mission.htmld/index.html.

91. AVERY, supra note 2, at 9 . For a brief discussion of the interconnectedness of agriculture, hunger, and the environment and a comprehensive bibliography, see Global Agriculture, Environment, and Hunger, Past, Present, and Future Links, available at Internet, http://www/ciesin.org/docs/004-147/004.html.

92. Asbjorn Eide, Strategies for the Realization of the Right to Food, in HUMAN RIGHTS IN THE Twenty-First Century: A Global Challenge 459, 460-72 (Kathleen E. Mahoney \& Paul Mahoney eds., 1993).

93. Id.

94. Id. 
in $1948 .{ }^{95}$ The UDHR embodied in international law, for the first time, a recognition of the right to food. ${ }^{96}$ The right to food, in order to be enforceable, must have a corresponding duty. But any hope of establishing a legally binding obligation associated with the right to food was substantially diminished when the Western States pressured the General Assembly to address the rights contained in the UDHR in two separate international covenants, the International Covenant on Civil and Political Rights (CCPR) and the International Covenant on Economic, Social, and Cultural Rights (CESCR). ${ }^{97}$ Article 11 of the CESCR specifically recognizes the right to food:

(1) The State Parties to the present Covenant recognize the right of everyone to an adequate standard of living for himself and his family, including adequate food . . . . The State Parties will take appropriate steps to ensure the realization of this right . . . .

(2) The States Parties . . . recognizing the fundamental right of everyone to be free from hunger, shall take, individually and through international co-operation, the measures, . . . needed:

(a) to improve methods of production, conservation and distribution of food by making full use of technical and scientific knowledge, ... . in such a way as to achieve the most efficient development and utilization of natural resources;

(b) [t]aking into account the problems of both foodimporting and food-exporting countries, to ensure an equitable distribution of world food supplies in relation to need. ${ }^{98}$

95. Id.

96. Donald E. Buckingham, A Recipe For Change: Toward An Integrated Approach To Food Under International Law, 6 PACE INT'L L. REV. 285 (1994). The Declaration in Article 25 states: "everyone has the right to a standard of living adequate for the health and well-being of himself and his family, including food, clothing, housing and medical care and necessary social services." Id.

97. See Asbjorn Eide \& Allan Rosas, Economic, Social and Cultural Rights: A Universal Challenge, in ECONOMiC, SOCIAL AND CULTURAL RIGHTS 15 (Asbjom Eide et al. eds., 1995). See also Robert Robertson, The Right To Food in Intermational Law, in HUMAN RIGHTS IN The Twenty-First Century: A Global Challenge 451 (Kathleen E. Mahoney \& Paul Mahoney eds., 1993).

98. International Covenant on Economic Social and Cultural Rights, G.A. Res.2200A, U.N. GAOR, 21st Sess., Annex, Supp.. No. 16 at 49, 1496th plen. mtg., U.N. Doc. A/6316 (1966). Among the 120 States to have signed the CCPR, only the United States and Haiti have not ratified the CESCR. See Eide, infra note 100, at 23. See also Philip Alston, U.S. Ratification of the Covenant on Economic, Social and Cultural Rights: The Need For An Entirely New Strategy, 84 AM. J. INT'L L. 365 (1990) (discussing the obstacles, both philosophical and political, to be overcome if the United States is to ratify the CESCR). The 
Despite the United Nations' repeated claims that "all human rights are universal, indivisible, and interdependent and interrelated"99 and the requirement that State obligations associated with economic, social, and cultural rights be implemented in good faith, ${ }^{100}$ their enforcement remains more a question of political will rather than a justiciable right. ${ }^{101}$ Some argue that fulfillment of the right to food must go beyond the focus on the ratio of food to population and the distribution of available food resources ${ }^{102}$ into an entitlement-based approach where the thinking shifts from "what exists, to who can command what." 103 This approach reaches the relationship between the hungry and the commodity (food) by recognizing, for example, one's entitlement to ownership in what one produces with one's own labor (among others). ${ }^{104}$ However, even as the world's democracies expand and entitlements such as the right to property become more commonplace, this paradigm must presume: (1) adequate global production of food, and (2) both international and domestic instruments that can facilitate distribution. For example, a treaty incorporating international trade liberalization and domestic policies consistent with that same international agreement that encourages production, competition, and free trade on the world market seem an essential foundation unless the entitlement approach be undermined. China's people could realize the incentive through an entitlement program

Covenant is nearly 30 years old, drafted in 1966; President Carter pursued ratification in 1978, but any inertia toward ratification has since stalled. Id. at 2 .

99. Eide \& Rosas, supra note 97, at 16 (quoting the World Conference on Human Rights: Vienna Declaration and Programme of Action, UN Doc. A/CONF.157/23, part I, para. 5).

100. Asbjorn Eide, Economic, Social and Cultural Rights As Human Rights, in ECONOMIC, SOCIAL AND CULTURAL RighTS 21 (Asbjorn Eide et al. eds., 1995).

101. Id. at 22. Civil and political rights remain justiciable primarily because they are considered "absolute," and they do not strain State resources, whereas economic, social and cultural rights require the larger costs of State welfare and, thus, are considered nonjusticiable. This analysis has been characterized as a "gross oversimplification." Id. at 38. However, considering policy and legislation involving international legal obligations for the United States, the reality of world hunger and the United States' refusal to ratify the CESCR tends to reinforce this interpretation. See Asbjorn Eide, Strategies for the Realization of the Right to Food, in HUMAN RIGHTS IN THE TwENTY FIRST CENTURY: A Global CHALlenGe 459, 463 (Kathleen E. Mahoney \& Paul Mahoney eds., 1993). But see Martin Scheinin, Economic and Social Rights as Legal Rights, in ECONOMIC, SocIAL AND CULTURAL RIGHTS 41-62 (Asbjorn Eide et al. eds., 1995) (demonstrating the justiciability of economic, social, and cultural rights as a realization of positive state obligations). See also Joy A. Weber, Famine Aid To Africa: An International Legal Obligation, 15 BROOK. J. INT'L L. 369 (1989) (discussing the legal obligation to assist famine victims under customary international law).

102. Asbjorn Eide, The Right To An Adequate Standard Of Living Including The Right To Food, in ECONOMIC, SOCIAL AND CULTURAL RIGHTS 89, 95 (Asbjorn Eide et al. eds., 1995).

103. Id.

104. Id. at 94 . 
to reap the rewards of their labor as their country rapidly industrializes. But, as their country loses land to deserts and development and struggles against the climatic forces, these entitlements cannot purchase nor trade for what has neither been produced nor made available on the world market. It follows that any corresponding duties associated with a recognition of the right to food will not likely affect global hunger without U.S. ratification of the CESCR. ${ }^{105}$ Yet, the obstacles to shifting public opinion and, hence, political priorities existed when the notion of "freedom from want" was first introduced, ${ }^{106}$ and similar obstacles remain today. ${ }^{107}$

105. Alston, supra note 17, at 370. See also Seymore J. Rubin, Economic and Social Human Rights and the New International Order, 1 AM. U. J. INT'L L. \& POL'Y 67, 73-80 (1986) (discussing the divergent views with regard to the economic policies that could contribute to the recognition of economic and social human rights); Robert L. Bard, The Right to Food, 70 lowa L. REV. 1279, 1289-90 (1985) (noting that even if the United States were to ratify the CESCR, the right to food is not likely to be established). Because of the consent clauses written into the covenant, nations have not accepted the right as customary international law. Furthermore,

asserting a duty on the rich to guarantee adequate food for the poor is a welfare concept, and few nations have achieved a guaranteed, minimally accepted life for their people. [E]xtending it to foreigners is grossly utopian. This does not mean that individual nations will not recognize obligations to less fortunate nations, only that they will refuse to accept this as a legally imposed obligation. Nation-states will insist on a right to retain absolute discretion in determining the level of their contribution to world welfare requirements.

Id. at 1289.

106. See AYN RAND, THE VIRTUE OF SELFISHNESS (1964):

There is no such thing as 'a right to a job' - there is only the right of free trade, that is: a man's right to take a job if another man chooses to hire him. There is no 'right to a home,' only the right of free trade: the right to build a home or to buy it. There are no 'rights to a "fair" wage or a "fair" price' if no one chooses to pay it, to hire a man or to buy his product. There are no 'rights of consumers' to milk, shoes, movies or champagne if no producers choose to manufacture such items (there is only the right to manufacture them oneself). There are no 'rights' of special groups, there are no 'rights of farmers, of workers, of businessmen, of employees, of employers, of the old, of the young, of the unborn.' There are only the Rights of Man - rights possessed by every individual man and by all men as individuals.

107. See also Alston, supra note 17, at 371 . The Reagan administration demonstrated rejection of economic, social, and cultural rights as human rights by deleting the associated sections from the annual Country Reports on Human Rights Practices. In June 1988, the Deputy Assistant Secretary of State for Human Rights and Humanitarian Affairs delivered a statement in which the myth that cconomic, social, and political rights as actual human rights was dispelled. Id. at 371 n.42. See also Peter Vale, Engaging The World's Marginalized and Promoting Global Change: Challenges For The United Nations at Fifty, 36 HARV. INT'L L. J. 283 (1995) (discussing the failure of the United Nations to successfully assist the marginalized people of the global community-evidenced by the 40 percent increase of those living in absolute poverty in the last 15 years. Yet, when emergencies exist, the will to solve international problems seems to manifest itself, consider the 1987 Montreal Protocol on 


\section{U.S. AgRiCULTURAL POLICY}

\section{A. History of U.S. Farm Policy}

Following the economic collapse of the economy by the end of the 1920's, President Franklin Roosevelt's administration initiated "New Deal" 108 legislation that represented significant change in national agricultural policy, ${ }^{109}$ and Congress passed the Agricultural Adjustment Act of 1933. ${ }^{110}$ The purpose of the legislation was to stabilize agriculture, help consumers by supporting commodity prices, and place farm income in parity with industry. ${ }^{11}$ Congress realized that U.S. farmers' productive capacity exceeded domestic demand, that cycles of overproduction and low prices were followed by short supplies and higher prices, and that those individual farmers whose output influenced only a fraction of total production had little influence on commodity prices. ${ }^{112}$ The Agricultural Adjustment Act of 1933 was the first major legislation to address these elements. ${ }^{113}$ After the Supreme Court invalidated part of the Act in 1936, ${ }^{114}$ Congress passed the Agricultural Adjustment Act of 1938. ${ }^{115}$ This legislation provided for

Substances that Deplete the Ozone Layer).

108. Agricultural and Farm Programs: Hearings to discuss the 1995 Farm Bill before the Senate Agriculture, Nutrition and Forestry Committee, 103rd. Cong., 2d. Sess. (1995) (statement of Senator Domenici, Chairman, Senate Budget Committee)[hereinafter Domenici, Testimony], available at Internet, http://www.hillnet.com: 80/farmbill/budget/domenici.anf.html.

109. Mark Ritchie, Lecture on "US Agricultural Policy: Back To The Future," Institute For Policy Studies, Minnesota Department of Agriculture, available at Internet, http://www. users.interport.net/ - mmaren/ritchie.html.

110. Id.

111. Cong. Rec., U.S. House of Rep. Mar. 21, 1933, at 695. See also Christopher Kelly, Rethinking the Equities of Federal Farm Programs, 14 N. ILL. U. L. Rev. 659 n.2 (1994). Parity concerns the comparison of farm family income to that of nonfarm family income. Id. at 659 n.4. See also S. Rep. No. 357, 101st Cong., 2d Sess. (1990), reporting on the original Senate bill to revise and extend agricultural price support and related programs including agricultural exports, conservation, and research. This bill eventually passed to become the Food, Agriculture, Conservation and Trade Act of 1990, Pub. L. No. 101-624, 104 Stat. 3359.

112. S. Rep. No. 357, 101 st Cong., 2d Sess. 18 (1990).

113. Id.

114. United States v. Butler, 297 U.S. 1 (1936). Justice Roberts held that the plan authorizing the Secretary of Agriculture to make contracts with farmers to reduce their productive acreage in exchange for benefit payments was a "plan to regulate and control agricultural production, [and was] a matter beyond the powers delegated to the federal government." Id. at 68 .

115. S. Rep. No. 357, supra note 112 , at 19. 
acreage allotments, marketing quotas for price control, and price supports. ${ }^{116}$ By this time the composition of the Supreme Court had changed and a challenge to the marketing quota provisions of the Act was held to be within the commerce power of Congress. ${ }^{117}$ In 1949, the 1938 Act was amended to establish permanent "parity-based" price supports. ${ }^{118}$ The Agricultural Adjustment Act of 1949 is the last permanent legislation on agricultural policy. However, since 1973, Congress has regularly amended the Act with legislation that expires every four or five years. ${ }^{19}$

In the Food and Agriculture Act of 1965, Congress set commodity price supports near to world levels in an attempt to determine real values under market forces with supply controlled through voluntary programs. ${ }^{120}$ In 1973, the Agriculture and Consumer Protection Act moved toward omnibus farm legislation incorporating food aid, trade, soil conservation, and food stamp provisions. ${ }^{121}$ Congress continued to enact farm bills in 1977 and 1981 to address overproduction and low prices, and by 1981 , what later became known as the " 80 's farm crisis" began. ${ }^{122}$ Farmland prices fell drastically, surplus approached near record levels, and commodity prices and

116. Id. The Act established the Commodity Credit Corporation (CCC) which still exists today. The $\mathrm{CCC}$ allowed for the protection of farm incomes by allowing farmers to borrow from the government at floor prices established by Congress. When large grain companies (who tend to control the price of grain through buying and selling) would set market commodity prices below the floor price, farmers could get the guaranteed floor price from the government on a loan and hold their grain until the demand was such that the grain companies would bid the price back up. As the program evolved, Congress set a ceiling price so that if the price went above the ceiling, the government would release maintained surplus onto the market to lower the price below the ceiling. Balance between supply and demand was controlled through supply management programs where farmers within a particular commodity group would vote to reduce their production. In order to make the programs function, a complex system of import quotas, tariffs, and import limits was established to maintain the supply-demand balance. See Ritchie, supra note 109.

117. Wickard v. Filburn, 317 U.S. 111 (1942). Under the Act's acreage allotment provision, a farmer's total production area was limited in an attempt to control supply (and thus the price) through market quotas. In 1941, farmers in the program received an average price of about $\$ 1.16$ per bushel compared to the world market price of 40 cents. Justice Jackson, considering the cumulative effect of individual farm production, held that under the commerce power Congress could regulate commodity prices by limiting the volume of the commodity on the market. Id. at 128-29.

118. S. Rep. No. 357, supra note 112 , at 19.

119. Id.

120. Id.

121. Id. Instituted in the Act were target prices and deficiency payments as the primary means of federal government support for agriculture. (Target prices are government guaranteed price levels, and deficiency payments go to qualifying farmers whenever market prices fall below target prices.) Id. This Act marked a change in strategy from one of stabilizing prices to one of direct income subsidies which remains today the method by which the government provides direct income support to farmers. See Ritchie, supra note 109.

122. See Ritchie, supra note 109. 
farm incomes were down. In 1983, the Reagan Administration implemented a substantial one-year acreage reduction program called the Payment-In-Kind (PIK) program. PIK paid farmers with government-owned grain if they reduced or eliminated their production of wheat and feed grains. The goal to reduce surplus and new production was the rationale behind the program that set aside fifty-five million acres of cropland and reduced corn production by one-half. ${ }^{123}$ Regardless, the PIK program only effectively reduced surpluses for one year and reserve stocks increased thereafter.

Unfortunately, in 1985, the omnibus farm bill essentially continued the older programs ${ }^{124}$ with supply control rooted in acreage reduction programs and deficiency payments. The Food Security Act of 1985, however, addressed soil conservation by establishing the Conservation Reserve Program (CRP). This provision paid farmers to withdraw land from production for ten years if it was subject to high erosion ${ }^{125}$ and further denied commodity payments to farmers who converted wetlands or highly erodible soil to cropland. ${ }^{126}$ In addition, the 1985 Act established the $0 / 92$ and 50/92 acreage diversion programs where farmers with base acreage in wheat and feed grains could receive ninety-two percent of their deficiency payments for not producing on any of their base land or, in the case of rice or cotton, on one-half of their base acreage. ${ }^{127}$ The payment share was reduced from ninety-two percent to eighty-five percent in the Omnibus Budget Reconciliation Act of 1993. ${ }^{128}$ The Export Enhancement Program (EEP) was also initiated as part of the 1985 farm legislation and allows for the use of export subsidies toward agricultural products dumped ${ }^{129}$ on the world market. ${ }^{130}$

The Food, Agriculture, Conservation, and Trade (FACT) Act of 1990 reauthorized various programs and statutes covering all of the federal food and agricultural policies. FACT updated the agricultural price support programs and revised programs involving agricultural trade, farm credit, agricultural research, and conservation. ${ }^{131}$ "The ultimate purposes of these provisions are to ensure consumers an abundance of food and fiber at reasonable prices, to maintain the competitiveness of American farm

123. Review of the Payment-in-Kind (PIK) Program,1983: Hearings Before the Committee on Agriculture, U.S. House of Representatives, 98th Cong., 1st Sess. 12 (1983).

124. Id. See S. Rep. No. 357, supra note 112, at 19.

125. Id.

126. See FAETH, supra note 88 , at 26.

127. Id.

128. Omnibus Budget Reconciliation Act of 1993, Pub. L. No. 103-66, 107 Stat. 312.

129. Dumping refers to the sale of imported goods in the U.S. market at prices below those set for the same goods in the exporters' home market, or lower than the cost of manufacturing and marketing the goods in that home market.

130. Food Security Act of 1985, Pub. L. No. 98-198, 99 Stat. 1354.

131. S. Rep. No. 357, supra note 112 , at 1. 
products while providing a fair return to producers, and to conserve the natural resources which serve as the basis for all agricultural production." 132 FACT contains a host of programs including non-recourse loans, marketing loans, deficiency payments, the conservation reserve program (CRP), conservation compliance, research and education, food programs, rural development, crop insurance, and credit and trade expansion programs among others. ${ }^{133}$ Notably, since the 1950's, each successive farm bill became more wide-reaching in scope, yet four main elements are identifiable through most of the legislation: (1) a price or income support program; (2) some type of stored surplus program; (3) a land set-aside program (land retirement); and (4) domestic and foreign food programs. ${ }^{134}$ These considerations in the 1995-96 farm bill intertwined with a budget reconciliation package that promised reductions in federal spending caused spirited debate. The pivotal question was whether Congress would again continue the status quo by extending the 1990 legislation, initiate gradual reduction of government programs over a period of several years, or make radical changes to eliminate programs and move toward trade liberalization requiring American farmers to compete in the world market. ${ }^{135}$

132. Id.

133. Food, Agriculture, Conservation, and Trade Act of 1990, Pub. L. No. 101-624, 104 Stat. 3359.

134. Id. See FAETH, supra note 88 , at 26 . The price support programs allow for deficiency payments determined by a farmer's base acreage for one or more of seven crops: wheat, corn, barley, oats, sorghum, rice, and cotton. The farmers who voluntarily participate are required to set aside a certain percentage of their acreage base in the Acreage Reduction Program (ARP). The government also provides non-recourse loans where farmers use crops for collateral. If the farmer defaults on the loan, the government's only recourse is to confiscate the crop. Id. Included in the 1990 farm bill are sodbuster and swampbuster provisions that discourage cultivation of marginal soils and wetlands. Depending on the circumstances, repeated violations of these provisions can result in a loss of federal benefits. Id. at 27.

135. See Saving World Wildlife-and the American Farm-with High Yields and Free Trade: Hearings before the Senate Agriculture Committee on the 1995 Farm Bill, 103rd Cong., 2d. Sess. (1995) (testimony of Dennis Avery, Director of Global Food Issues for the Hudson Institute), available in WESTLAW USTESTIMONY database at 1995 WL 100509 [hereinafter Avery, Testimony]. "It is now clear that for 60 years the U.S. has been running the second-dumbest farm policy in the history of the modern world. Only communal farming, invented by Joseph Stalin, has had a worse record of achievement than America's farm price supports and cropland diversion." Id. See also Roy Frederick, A Fateful Month Ahead for Farm Bill, Ag Policy Update, No. 20 Oct. 13, 1995, available at Internet, http://ianrwww. unl.edu/farmbill /apu 20.htm; 1995 Farm Bill: Hearings before the Senate Committee on Agriculture, 103rd Cong., 2d. Sess. (1995) (statement of the Hon. Calvin M. Dooley, Congressman, 20th District, California), available in WESTLAW USTESTIMONY database at 1995 WL 113201(F.D.C.H.).

U.S. farm policy was born in 1933 . . . [with] the New Deal farm programs as a temporary solution to deal with an emergency. Sixty years later, we are still using those same solutions as the basis for our farm policy . . . . A continued 


\section{B. The GATT}

Final resolution of the $1995-96$ farm bill necessarily involved consideration of the United States' position in the world marketplace as impacted by the conclusion of the Uruguay Round negotiations of the GATT. ${ }^{136}$ By the year 2000, the Uruguay Round Agreements Act ${ }^{137}$ (URA) requires a twenty-one percent decrease in the export of subsidized goods and a thirty-six percent decrease in funding of export subsidies compared to

reliance on programs that require farmers to set aside up to 15 percent of acreage is a prescription for reducing the U.S. share of the international market and declining profitability in the long term. Every acre that we take out of production is not driving up prices, but rather is presenting an opportunity for our foreign competitors to capture markets that should be the domain of U.S. farmers. The time has come to break our addiction to a farm policy that seduces us with income supports but leads us down a path of reduced opportunities. It is time that we embrace a farm policy that encompasses three fundamental objectives: [m]arket expansion, . . . [r]isk management, . . . [and] [m]aintaining competitiveness.

Id. Cf. Agricultural Trade: Hearings before the General Farm Commodity Subcommittee on the 1995 Farm Bill, 103rd Cong., 2d. Sess. (1995) (statement of John Burritt, President of the Northern Sun Division of Archer Daniels Midland Co., Decatur, III.), available in WESTLAW USTESTIMONY database at 1995 WL 354988 (F.D.C.H.) (testifying on U.S. oilseed policy, export potential, and associated trade barriers while encouraging continued use of support programs).

136. The General Agreement on Tariffs and Trade, opened for signature Oct. 30, 1947, 61 Stat. pts 5-6, 55 U.N.T.S. 187 [hereinafter GATT ]. The GATT is a formal multilateral agreement whose purpose is to expand and liberalize world trade. GATT provisions regulate the use of trade barriers and eliminate some of the confusion involved in international trade. GATT also provides for a process to settle trade disputes and negotiate the liberalization of tariff and nontariff barriers. However, prior to the Uruguay Round, GATT did not address domestic agricultural policies which allowed implementation of nontariff barriers. See Liane L. Heggy, Free Trade Meets U.S. Farm Policy: Life after the Uruguay Round, 25 L. \& POL'Y INT'L BUS. 1367 (1994). The Uruguay Round began in September 1986 as the eighth round of negotiations to GATT. Originally, the Round was to be completed by the end of 1990 , but primarily because of a basic disagreement on agricultural reform, the negotiations stalled. The United States wanted to phase out agricultural subsidies affecting international trade, but the European Community (EC), whose Common Agricultural Policy (CAP) allows for extensive subsidizing of agricultural production to counter imports, opposed the plan. After seven-plus years of negotiations, 117 countries concluded the Final Act of the Uruguay Round (URA) on December 15, 1993. The URA involves more than 26,000 pages and represents the most comprehensive international trade agreement in history. The successor to GATT, the World Trade Organization (WTO) was also established in the URA negotiations. S. Rep. 412, 103rd Cong., 2d Sess. (1994) (Senate report on Uruguay Round Agreements Act, Pub. L. No. 103465, 108 Stat. 4809 (1994)).

137. Uruguay Round Agreements Act, Pub. L. No. 103-465, 108 Stat. 4809 (1994). 
prevailing 1986-90 levels. ${ }^{138}$ Nontariff import barriers (NTB's), such as quantity restrictions or even outright bans, import levies, minimal import pricing, and discretionary import licensing, must all be converted to tariffs and reduced by an average of thirty-six percent by the year 2000 , and each individual tariff must decline fifteen percent. ${ }^{139}$ The URA also requires that developed countries reduce domestic subsidies twenty percent over the next five years as compared to 1986-88 levels. ${ }^{140}$ Although the URA represents major reform by bringing agriculture under a multilateral discipline, the level of domestic protection is likely to remain high ${ }^{141}$ because the URA reduction measures exclude direct-income support (including U.S. deficiency payments). ${ }^{142}$ Still, world market prices over the next decade will likely be substantially influenced by GATT and the $1995-96$ farm bill. ${ }^{143}$

\section{Forces Shaping the 1995-96 Farm Bill}

The world has changed dramatically since the first farm legislation in 1933, even though the basic policy remains in effect today. ${ }^{144}$ The changes over the past sixty years and particularly the evolution in American agriculture will have a substantial influence on the extent to which the status quo in farm legislation continues. For example, in 1933, twenty-five percent of the total U.S. population were farm households that generated more than ten percent of the gross domestic product (GDP). ${ }^{145}$ In 1995, less than two percent of the population lived in farm households and they generated less than two percent of the GDP. ${ }^{146}$ The original concern with parity between farm incomes and industry no longer applies as the income for farm households now exceeds the average for all U.S. households. ${ }^{147}$ However,

138. Norman S. Fieleke, The Uruguay Round of Trade Negotiations: An Overview, NEw ENG. ECON. REV., May 15, 1995, at 3, 8, available in WESTLAW, TRD \& IND database.

139. Id. The process of converting NTB's is known as tariffication.

140. Id.

141. Merlinda D. Ingco, Agricultural Liberalization in The Uruguay Round, FIN. \& DEV., Sept. 1995, at 43, available in WESTLAW, TRD \& IND database.

142. Id.

143. GATT Market Impact Depends on U.S. Policies, AGRA EUR., June 30, 1995, at 3, available in WESTLAW, TRD \& IND database.

144. See Avery, Testimony, supra note 135.

145. See Domenici, Testimony, supra note 108. products).

146. Id. (Approximately 800,000 farms produce 96 percent of America's agricultural

147. Daryll E. Ray, The Economic Setting for U.S. Agriculture, available at http://ianr www.unl.edu/farm bill/setting.html.

Farm households averaged $\$ 39,007$ in income in 1990 , which was $\$ 1,600$ above the average income for all households, but only $\$ 5,742$ of that was from their farms. Nearly three-fourths of farm operator households operate farms with less than $\$ 50,000$ in gross sales and, on average, lose money on farming 
farmers' non-farm income today far outweighs their farm income. ${ }^{148}$ Even more telling is that "[o]ver the past ten years, American taxpayers made payments totaling $\$ 108.9$ billion through the federal farm subsidy programs, [b]ut just two percent of the programs' recipients . . . received an astronomical 26.8 percent of the subsidies, $\$ 29.2$ billion in all." 149 Further evidence suggests that the farm programs are wrought with fraud and corruption. ${ }^{150}$ With an increased emphasis to balance the federal budget, the

ld.

operations.

148. See Domenici, Testimony, supra note 108. The Congressional Budget Office (CBO) reported that all farm income filers showing a negative income-1.4 million filers with a negative income of $\$ 13$ billion-also showed positive income of more than $\$ 70$ billion meaning that most farmers will be affected by non-farm fiscal policy much more than they will by farm programs. Id.

149. The Cash Cropper, (Farm Subsidy Study conducted by the Environmental Working Group), available at Internet, http//www.ewg.org. The study revealed that the top 2 percent of recipients averaged $\$ 485,000$ each in government farm payments in the last 10 years which was more than 13 times as much as the average recipient. Over the last decade, the top 60,000 recipients averaged more in federal farm subsidy payments each year than the typical American family earned on average each year from all sources. The top 2 percent of individual recipients from 1985 through 1994 totaled $\$ 20.83$ billion which is almost 25 percent of the total payments to individuals; each averaged over $\$ 400,000$ apiece-more than 12 times that paid to the average individual recipient. The report's revealing message is that almost 25 percent of all subsidy payments made over the last 10 years went to the top 2 percent of recipients! See Rethinking the Equities of Federal Farm Programs, supra note 111 (arguing that farmers should not be given income based on socioeconomic status). See also Paul Faeth, Let's Get Welfare Farmers off the Dole, CHI. TRIB., Oct. 6, 1995, at 21 (Forty percent of subsidy payments go to farmers with a net income of $\$ 100,000$ and a net worth of $\$ 750,000$ or more; subsidizing farmers is not enhancing rural development). FAETH, supra note 88, at 23. Faeth contends that because commodity-support programs link benefits to the acreage historically under production, the largest benefits go to the largest producers. In 1991, 30 percent of the subsidy payments went to the largest 5 percent of all farms. These farms accounted for 57 percent of gross cash income. The smallest [farm producers] 69 percent received only 17 percent of program payments and accounted for only 10 percent of gross cash income. But see Lee Smith, How To Cut Farm Spending; The Government Should Quit Paying Crop Subsidies and Instead Fashion a Straightforward Welfare Program for Farmers Who Can't Hack it in the Open Market, FORTUNE, Nov. 10,1986, at 97, available in WESTLAW, TRD \& IND database.

150. Fox in the Henhouse, (Environmental Working Group analysis of farm subsidy payments over the last 10 years), available at Internet, http://www.ewg.org. "Federallyfunded county office employees and farmer committee members often participate more frequently in the very programs over which they exercise greatest local control than the average recipient, and they receive higher than average payments." Id. Between 1985 and 1994 , more than $\$ 852$ million was paid in federal farm subsidies to USDA committee members. All of the top 100 county committee recipients got more than $\$ 547,000$ over the last 10 years, and more than 1000 farmers on USDA county committees received in excess of $\$ 250,000$ each in farm subsidy payments per year of participation in farm programs. Id. In 1994 , a California government employee was caught embezzling $\$ 165,000$ from the USDA; several others were caught fraudulently issuing checks for more than $\$ 270,000$. The USDA 
inequities in farm payments and the ethical breakdown of the program's infrastructure should provide further incentives for drastic reduction in spending-considering that the farm bill will control about ten percent of the total non-social security budget amounting to $\$ 250$ billion. ${ }^{151}$ Implementing change will be difficult, and some would argue that the optimum moment for reforming farm trade has passed us by. "That moment came and went with the 1990 farm bill and the Uruguay Round of the GATT . . . now American farmers will be asked to take bigger risks with smaller payments because the U.S. government simply lacks the cash to cushion the transition very much." 152

Still, other changes provide an impetus to refocus U.S. farm policy on a global marketing strategy acknowledging the emerging opportunities in the world food market. The North American Free Trade Agreement (NAFTA) and especially the Uruguay Round of GATT have deconstructed many of the trade barriers that hindered U.S. farmers in the past. Arguably, government programs have driven farmers to produce for the government instead of the market by influencing their decisions on what to plant and on how many acres. This philosophy must change as we now know that over the next thirty years eighty-five percent of the world's consumers will live in Africa, Asia and Latin America, ${ }^{153}$ and that at least in Asia and Latin America where income is rising rapidly, local food production is not keeping pace. ${ }^{154} \mathrm{We}$

has data that shows 1783 farms violated federal conservation laws dealing with the protection of highly erodible soils or wetlands; yet, the USDA paid more than $\$ 18$ million to these participants who applied for subsidies where benefits could have been denied or substantially reduced.

151. See Domenici, Testimony, supra note 108.

152. See Avery, Testimony, supra note 135.

153. Mark Drabenstott, New Directions for U.S. Agricultural Exports, available at Internet, http://ianrwww.unl.edu/farmbill /exports.html. See Global Economic Prospects and the Developing Countries 1995, available at Internet, http://www.worldbank.org/html/extpb/ GepEnglish.html\#Global (discussing the benefits of integrating developing countries into the global economy as a major opportunity to improve the welfare of both. "The global economic environment is brighter than it has been for many years and provides a favorable setting for continued integration of developing countries into the world economy.").

154. Drabenstott, supra note 153 . The share of grain consumption produced locally averages 95 percent in Latin America, 92 percent in Asia, and 75 percent in Africa. See Workers in an Integrating World, WORLD DEVELOPMENT REPORT 1995, available at Internet, http://www.worldbank.org/html/extpb/wdr95/WDRENG.html. Between 1970 and 1990 manufacturing wages in East Asian economies rose 170 percent while manufacturing employment increased 400 percent. About 1.4 billion of the 2.5 billion people working worldwide lived in poor countries with a per capita income below $\$ 695$ in 1993; 660 million lived in middle-income countries, and 380 million lived in high income countries with a per capita income of more than $\$ 8,626$ in 1993 . In poor countries, 61 percent of the labor force works in agriculture, 22 percent in rural nonfarm and urban informal sectors while 15 percent have wage contracts primarily in urban industrial and service employment. Middle income countries employ 29 percent on farms, 18 percent in rural and urban informal jobs, and 46 
also know that higher incomes lead to improved diets which indicate that as population expands in these regions, the growing deficit of food production promises growth in world food trade. ${ }^{155}$ Because "Asia, Latin America, Russia, and Africa will remain substantial importers of grain . . . it makes eminent sense to allow the world's most productive agricultural system, that of the United States, to play a large role in meeting the expected growth in demand." 156 In order for America's farmers to exploit this coming surge they must have the incentive to produce which would require the elimination of current acreage idling programs that "take 50 to 60 million acres out of production." 157 "U.S. land-idling programs only give incentives to producers in other nations, especially in South America, to produce more and invest in improving their handling and transportation systems," 158 while "America has the world's biggest comparative advantage . . . the climate [temperate] and cropland cleared and ready . . . the world's best infrastructure, best research, and the best trained farm managers; . . . [n]o other country in the world could expand its farm output without investing billions of additional dollars and years of time." 159

Domestic and global environmental concerns also dictate significant revision of U.S. farm programs. In the United States:

percent in service and industry employment. Wealthy countries show 4 percent employed in agriculture, 27 percent in industry, and 60 percent in service jobs. The report also indicates that although low-income countries have the majority of the world's agricultural labor force (on family farms), they also make up almost half of the world's industrial workers.

155. Drabenstott, supra note 153. See also Avery, Testimony, supra note 135. "In 1933, it looked as though there was always more food demand coming. Today, we're looking at the last and biggest surge in world food consumption. If American farmers miss this food train, they will never catch another." Id.

Most of these food exports would go to burgeoning economies of Asia. Currently there are about 3 billion Asians, averaging about 14 grams of animal protein per day ... [ [t]hat compares with 71 grams for Americans and 55 for Japanese. By the year 2030, I am certain that the world will need to supply at least 55 grams of animal protein per day for 4 billion Asians . . . [which] represents almost a six-fold increase in protein calories from today. It will be the biggest surge in farm demand the world has ever seen.

Id.

156. Duesterberg, supra note 25.

157. Id. See Panorama From Brussels EU Grain Prices; What Happens When The Bubble Bursts?, AGRA EUR., Oct. 28, 1994, at 1-3 (noting that the United States currently has arable land set aside that is equal to the EU's total cereal growing area and the only way the EU can match production with demand is to eliminate both subsidies and market support). See also UK Farmers Join Call to Cut Set-A side Rate, AGRA EuR., Sept. 1, 1995, at 4 (due to the GATT cuts in export subsidies the EU faces the risk of losing a share of both the domestic and international market calling for a further reduction in land set aside).

158. Id.

159. U. S. Farm Policy in a Real World Context, supra note 47. 
farm supports contribute to soil erosion, overuse of agriculture chemicals, and loss of wildlife habitat; [b]y raising the payments farmers receive for their crops but restricting the acreage they can plant, policies encourage intensive cropping and input use on land that is planted; . . . contamination of underground and surface waters by nitrates and pesticides has emerged as a serious problem in many farming regions. ${ }^{160}$

In addition, we now know that: (1) today's farmers worldwide have to triple their output if the world is going to be fed in $2050 ;{ }^{161}$ (2) that agriculture currently occupies one-third of the world's land surface leaving another onethird as forests; ${ }^{162}$ (3) that a "high proportion of the world's best and safest land lies in the U.S.; and (4) over sixty percent of the cropland enrolled in the Conservation Reserve Program (CRP) is composed of soil types bestsuited to crops." 163

If the United States Congress is going to impact whether people starve or not over the next fifty years; whether the forests continue to be plowed down or remain intact for the world's wildlife; and whether America's farmers continue high input chemical farming, they must develop a farm program that does not waste the world's best cropland and at the same time endorses free trade of global agricultural products. ${ }^{164}$

The Clinton Administration has announced that over the next five years, the United States, utilizing the Export Enhancement Program (EEP),

160. FAETH, supra note 88, at 24 . Faeth states that "[s]ince 1964, agricultural pesticide use in the United States has tripled, and fertilizer use has risen by two-thirds, but cropland has only expanded by 10 percent . . . [and that] off the farm, agriculture has become the single largest diffuse (or nonpoint) source of water pollution." Id. at 25 . In addition, "the surest path to fiscal and environmental gain is to remove economic distortions created by the current commodity programs." Id. at 1 . Faeth also suggests that a farm bill written to save tax dollars and protect the environment necessarily increases the percentage of commodity-program land on which farmers can choose to plant; this would allow for program savings that could be used to support farm income directly. See also Weed Killers by the Glass, available at Internet, http://www.ewg.org (A study conducted by the Environmental Working Group 1995 found agricultural weed killers (herbicides) including atrazine, cyanizine, and metolachlor, among others, were in the tap water of 28 out of 29 cities tested-average levels exceeded federal standards in 13 cities.).

161. See U.S. Farm Policy in a Real World Context, supra note 47.

162. Id.

163. AVERY, supra note 2, at 360 .

164. Dennis Avery \& Dave Juday, A Contract With Rural America, HudSON BRIEFING PAPER, Oct. 1995. 
will aim to increase agricultural exports by fifty percent over 1994 levels. ${ }^{165}$ Agricultural exports for 1995 are expected to be a record high $\$ 53$ billion; this total will increase the United States' share of world agricultural trade to twenty-three percent and make it the leader in world exports of agricultural products. ${ }^{166}$ However, since the EEP has been restricted by the Uruguay Round, its potential import may be reduced, although some argue that the EEP operates as a trade restriction rather than an enhancement. ${ }^{167}$

165. International Trade, USDA Wants U.S. to Boost Exports 50 Percent By Year 2000, BNA Oct. 27, 1995. (Agriculture Secretary, Daniel Glickman, announced the U.S. Department of Agriculture's long term strategy on October 25. The report indicates increasing dependence on the developments in the Asia and Pacific Rim region where the USDA will focus export assistance efforts.)

166. Hearings Before the House Committee on International Relations, Subcommittee on Economic Policy and Trade, U.S. House of Rep. Oct. 19, 1995 (Testimony of August Schumacher, Jr., Administrator of the Foreign Agriculture Service). Schumacher states that the increasing export share means the Export Enhancement Programs (EEP) are proving successful and will play a vital role in the new farm bill as 30 percent of all acres planted end up are being exported to meet the needs of the world's consumers, 96 percent of whom live outside the United States. In addition, the USDA administers the GSM-102 Export Credit Guarantee Program and GSM-103 Intermediate Export Credit Guarantee Program. Under these programs the government guarantees payment to exporters of U.S. agricultural products or their banks if the foreign purchaser fails to pay. In effect, these programs encourage U.S. lending institutions to extend credit while allowing foreign purchasers to defer payment. The Agricultural Trade Act of 1978 , as amended, requires $\$ 5$ billion in GSM-102 guarantees to be available each year through 1995 . The GSM-103 requires not less than $\$ 500$ million through 1995, and the EEP requires $\$ 500$ million in funds or commodities each year through fiscal 2001. Id.

167. Hearings Before the Subcommittee on International Economic Policy and Trade of the Committee on International Relations, U.S. House of Rep. Oct. 18, 1995 (testimony of Robert W. Kohlmeyer, Executive Vice-President of World Perspectives, Inc.) (WPI is a private information, analysis, and consulting firm specializing in agricultural and trade policy). Kohlmeyer stated that the EEP was established to fight unfair trade practices abroad but is rationalized as international trade assistance and is being used for political purposes to balance the ineffective domestic policies. In addition, the EEP distorts market conditions to buyers and sellers causing poor decisions. Most importantly, "export subsidies do not create demand, nor increase total trade." Id. The United States share in wheat trade is lower than it was prior to the program; the trade we gained through these subsidies is offset by the trade we lost to competitors. Compare Schumacher, supra note 166, who credits the EEP with the record exports even though the USDA (due to market conditions) stopped using subsidies on exports of bulk grains early this year and on export sales of edible oils more than a year ago. See also World Grain Market: Can Prices Be Sustained?, AGRA EuR., Aug. 11, 1995, available in WESTLAW, TRD \& IND database. "Given the favorable relationship between U.S. domestic prices and world prices - even at lower levels - and the facility to subsidize exports still retained in the 1994 GATT agreement, there is every incentive for the U.S. to remove production controls and maximize production and exports." Id. See also Expon Subsidies Make U.S. Less Competitive, Says Louis Dreyfus Corp., AM. INST. OF FOOD DISTRIBUTION, INC., May 1, 1995, available in WESTLAW, PTS-NEWS database (Export subsidies that support U.S. commodity prices above the world market price tend to reduce U.S. exports.). 


\section{The Freedom to Farm Act of 1995}

In August 1995, as part of the Republican reform movement, the Freedom to Farm Act of $1995^{168}$ was introduced in the House of Representatives. The bill represented a significant departure from the status quo of past farm programs and by placing a cap on farm subsidies would have gotten farmers growing for the market instead of the government-presuming that farmers could prosper by producing for the surging world market demand. ${ }^{169}$ The bill would amend the Agricultural Adjustment Act of 1949 and reduce farm commodity programs by $\$ 13.4$ billion from 1996 to $2002 .{ }^{170}$ In addition, the bill would have eliminated all acreage set-asides in the farm reserve policies of the past, ending the practice of paying farmers not to plant while increasing the farm acreage ineligible for deficiency payments from fifteen to thirty percent and guaranteeing a declining payment to farmers over the seven-year period. ${ }^{171}$ The bill would have renewed price support loan programs on wheat and feed grains and ensured compliance with the farm conservation and wetlands protection programs of the Food Security Act of 1985 using "market transition contracts." 172 These contracts make annual payments conditional on compliance with those programs. ${ }^{173}$

The Freedom to Farm Act sparked controversy both in Congress ${ }^{174}$ and on the farm. Some believe that the plan emphasized the inequities between large and small farm producers ${ }^{175}$ and locked in subsidies that are not

168. H.R. 2195, 104th Cong., 1st Sess. (1995).

169. James Kuhnhenn, Divided GOP Hurts Roberts Farm Reforms, KANSAS CITY STAR, Sept. 29, 1995, at A1. See Farm Groups Anxiously Await Congress' Aid Cuts: Longtime Subsidies May Change or End for Cotton, Dairy, Grains, STAR-LEDGER, Oct. 1, 1995. See also Benefits, Disadvantages of New Farm Bill Options Weighed, MILLER \& BAKING NEws, Sept. 19, 1995, at 26.

170. H.R. 2195, 104th Cong., 1st Sess. $\S 102$ (1995) (Total expenditures for the Commodity Credit Corporation may not exceed $\$ 43.2$ billion.) See also James Brooke, Freedom to Farm Bill Offers Kansasan Vision of Choice for His Open Fields, N. Y. TIMES NEWS SERVICE, Sept. 26, 1995.

171. H.R. 2195, 104th Cong., 1st Sess. $§ 101$ (1995).

172. Id.

173. Under the terms of a market transition contract, the producers shall agree, in exchange for payments under the contract, to comply with the conservation compliance plan for the farm prepared in accordance with Section 1212 of the Food Security Act of 1985 (16 U.S.C. $\$ 3812$ ) and wetland protection requirements applicable to the farm under subtitle C of Title XII of such Act (16 U.S.C. $\$ 3821$ et seq.).

174. James Kuhnhenn, Divided GOP Hurts Roberts Farm Reforms, KANSAS CITY STAR, Sept. 29, 1995.

175. "Once again, the rich and powerful are exempted from the rigors of deficit reduction, leaving farm families of modest means to shoulder the burden . . . [s]imply put, the cuts are unfair." Big Farms Will Still Receive Big Payments Under GOP Bill, Critics Claim, Rocky MTN. NEWS, Oct. 22, 1995 (quoting Chuck Hassebrook, analyst with the 
needed. ${ }^{176}$ Others think that allowing America's farmers to increase production for the market would result in higher food prices ${ }^{177}$ and at the same time cause a crash in commodity prices that would further imperil the farmer's economic status. ${ }^{178}$

The resentment for ending sixty-year-old New Deal policies manifested itself when the Freedom to Farm plan was voted down in the House Agricultural Committee. ${ }^{179}$ This prompted supporters of the bill to transfer jurisdiction of the proposal to the House Budget Committee where it was incorporated into the overall GOP budget reconciliation package that President Clinton subsequently vetoed. ${ }^{180}$

Center for Rural Affairs in Walthill, Nebraska).

176. See Brooke, supra note 170.

177. Risking the Harvest, CourIER-JOURnal (Louisville, Ky.), Sept. 27, 1995. See AVERY, supra note 2 , at 362 . The USDA reports that U.S. consumers spend 11 percent of their incomes to support one of the world's highest standards of eating-Europe charges consumers double what Americans pay, and Japan is two times as high as Europe. Id.

178. Risking the Harvest, supra note 177. If forced to compete without subsidies in the world market, American farmers would lose out to cheap labor in undeveloped countries and heavily subsidized European farmers. See Maurice Schiff \& Alberto Valdes, The Plundering of Agriculture in Developing Countries, available at Internet, http:// www.worldbank.org/html/extpb/PlunderAgri.html. Economists with the World Bank's International Economics Dept. recommend that large income gains can be realized from agricultural reform if direct taxation of exports and direct protection of imports are eliminated as well as all import quotas, licenses, state trading companies, and internal marketing regulations that prevent the free flow of goods and services. Moreover, social objectives such as protecting the poor do not justify agricultural price tampering-the impact is marginal, undeterminable over time, and implemented at the expense of agricultural growth and agricultural incomes. Id.

179. Bruce Ingersoll, Four Republicans Delay GOP's Plan To Revamp Nations Farm Programs, WALL ST. J., Sept. 22, 1995.

180. Steven Lee, GOP Conferees Approve Farm Bill Cutting Spending 23\% Market Safeguards Retained for Cotton; Clinton Promises Veto, Dallas MORNING NEws, Nov. 16, 1995. See Farmers To Profit Hugely If Subsidy Programs Die '49 Law Would Force U.S. To Buy Wheat, Com Crops, ARIz. REPublic, Dec. 11, 1995 (President Clinton vetoed the proposed budget package which included a version of the GOP Freedom To Farm Act; unless a budget agreement is reached which includes a farm bill, the last permanent legislation (1949 Agricultural Adjustment Act) will kick in, meaning that the government would have to purchase all of the 1996 wheat crop and most of the corn crop-a "doomsday payout" threatened by the Clinton administration that could cut wheat production by 20 percent and cost the government billions.) See also Robert Greene, Farm Bill Races Against Time; Approaching Growing Season Forces Federal Hand, DENVER POST, Jan. 19, 1996. This political gridlock is patently unfair to American farmers who are now trying to plan the type and amount of grain crops to plant in the spring of 1996, as well as purchase fertilizers and chemicals. Moreover, 15 high-ranking agricultural economists have requested that President Clinton accept the Republican farm policy proposal phasing out subsidies including: Donald Paarlberg, chief agricultural economist for the Eisenhower, Nixon, and Ford administrations; Willard Cochran, Director of Agricultural Economics for President Kennedy; John Schnittker, Assistant Agriculture Secretary for President Johnson; Dale Hathaway and Lynn Daft, 


\section{E. Agricultural Resources Conservation Act of 1995}

The Senate Agricultural Committee approved the Agricultural Resources Conservation Act of 1995, ${ }^{181}$ a farm bill that would amend the Food Security Act of 1985 . The bill achieved more than thirteen billion dollars in savings over seven years by reducing the acreage eligible for current program subsidies-a marked contrast to the Freedom to Farm bill that eliminated the current price support programs. The Senate bill also cut funding to the Market Promotion Program by thirty-five million dollars as well as a cut of more than $\$ 700$ million in the Export Enhancement Program. ${ }^{182}$ The bill limited acreage in the Conservation Reserve Program, effectively reducing government payments by lowering the amount of land farmers take out of production. ${ }^{183}$ It also capped subsidies available to the Commodity Credit Corporation while doubling the amount of flex acreage (from fifteen to thirty percent) that would not qualify for subsidies, ${ }^{184}$ in effect, saving about $\$ 8.8$ billion $^{185}$ over seven years. The Senate version of the 1995 farm bill, however, was essentially ignored by House and Senate conferees when they approved a version of the Freedom to Farm Act that was incorporated into the budget reconciliation package. ${ }^{186}$

agricultural economists for President Carter; Robert Thompson and William Lesher, Chief Agricultural Economists for President Reagan; Daniel Sumner and Bruce Gardner, Chief Agricultural Economists for President Bush; and Robert Innes, agricultural economist for President Clinton's Council of Economic Advisors who is now at the University of Arizona. Experts Urge Clinton to Back GOP Farm Bill, the President Insists that the Freedom to Farm Act 'Slashes the Farm Safety Net, ' COURIER-JOURNAL (Louisville, Ky.), Dec. 15, 1995. Since the farm bill is caught up in budget negotiations and reverting back to the 1949 law is not practical, the extension of the current law through this election year is likely and could further delay much needed reform. See Lott Outlines Legislative Schedule For Second Session, Jan. 18,1996 , available in WESTLAW BNA-DNEWS database.

181. S. 854, 104th Cong., 1st Sess. (1995).

182. Farm Bill Provisions, INDIANAPOLIS STAR, Oct. 24, 1995.

183. S.854, 104th Cong., 1st Sess. $§ 1231$ (1995). See Farm Bill Provisions, supra note 182.

184. S.854, 104th Cong., 1st Sess. $§ 1241$ et seq. (1995).

185. See Farm Bill Provisions, supra note 182.

186. See Christopher George, GOP Completes Welfare-Overhaul Plan; Veto Still Looms, Clinton Aides Suggest, WaLl St. J., Nov. 13, 1995. 


\section{F. Federal Agriculture Improvement and Reform Act (FAIR) of 1996}

With pressure mounting from election year politics ${ }^{187}$ and the spring planting season having arrived, Congress passed the Federal Agriculture Improvement and Reform Act of 1996 (FAIR). ${ }^{188}$ Surprisingly, the bill incorporated much of the "Freedom to Farm" bill introduced earlier in the House and allegedly ends sixty-year-old New Deal policies by replacing them with a market-based philosophy. ${ }^{189}$ Ironically, instead of saving billions of dollars as the Republican reform movement has promised, the farm bill could end up costing several million dollars more than if the old law had been extended. FAIR guarantees fixed but declining (transition) payments to farmers over the next seven years regardless of whether they farm or not and regardless of market prices. ${ }^{190}$ These direct payments are in lieu of the "deficiency" payments of prior farm programs that only became necessary if farmers could not obtain adequate income from the market. ${ }^{191}$ Some argue that the direct payments constitute consideration for the promise not to take additional payments after seven years. ${ }^{192}$ However, there is no guarantee that subsidy payments will end in 2002 because the 1949 Agricultural Adjustment Act was left in place as the last permanent legislation when the 1996 law expires-meaning that planting restrictions and subsidies could resume. ${ }^{193}$

187. James Kuhnhenn, As Caucuses Loom, Bill Withers on Vine, The Inability to Pass Agriculture Reform Hurts Republican Hopefuls, KANSAS CITY STAR, Feb. 7, 1996, at A4; Flynn McRoberts, Stalled Farm Bill Dogs Dole in Iowa Uncertainty Over Legislation Intensifies Questions About Senate Majority Leader, CHI. TRIB., Feb. 7, 1996.

188. Federal Agriculture Improvement and Reform Act of 1996, Pub. L. No. 104-127, 110 Stat. 888.

189. Id. § 101 et seq.

190. Id. \$§111-117.

191. Even though restrictions on what crops a farmer may plant and how much they are allowed to grow have been abandoned, other inequities are created. As originally proposed the "Freedom to Farm" plan was supposed to save the taxpayers $\$ 13$ billion. The cost of FAIR is estimated at $\$ 35$ billion over seven years versus projected spending of $\$ 13$ billion under current law. For the largest 11 percent of corn farmers who receive 60 percent of the corn-subsidy payments, the average payment will be about $\$ 23,000$ per year over and above the $\$ 250,000$ average income from crops. The top four percent of wheat producers would receive an average payment of $\$ 15,000$ over and above an average farm income of $\$ 155,000$ per year. This represents windfall benefits to producers-payments that are not necessary when market prices are high. Mark Epstein, Farm Bill a Bumper Crop of Handouts, ARIz. REPUBLIC, Mar. 26, 1996, at B5.

192. Victor Davis Hanson, Taxpayers Now Asked to Shell Out $\$ 36$ Billion for Agribiz, SACRAMENTO BEE, Mar. 24, 1996, at FO1. Direct payments are in addition to profits made due to the market prices for corn and wheat nearing 20 -year highs.

193. Eric Schmitt, Farm Bill Pulls in Safety Net Supporters of Small Farmers are Expected to Take Another Run at The Legislation Next Year, ORLANDO SENTINEL, Mar. 31, 1996, at G1. (President Clinton indicates that he will propose legislation to strengthen the farm 
Other provisions demonstrate why FAIR is a kind of oxymoron for the official propaganda versus what is contained in the bill. Specifically, price supports for the sugar and peanut programs and price-fixing for milk all indicate the widening gap between the unconscionable rhetoric and the subsidized reality that cost consumers two billion dollars per year in artificially inflated prices. ${ }^{194}$ Essentially, the bill provides for no incomebased limitation, and payments are based on who owns the farmland instead of who actually farms it-allowing windfall payments to large agribusinesses at a time when market prices for these commodities are strong. At the same time, nearly half of all farm products are not produced under any government programs including potatoes, livestock, poultry, and most fruits and vegetables. ${ }^{195}$ Yet, these producers operate in a free market with prices that are more volatile than the grain market and with no interest in getting a handout from the government. ${ }^{196}$

Environmental measures within FAIR include extending the Conservation Reserve Program and the Wetlands Reserve Program with 34.6 million and 975,000 acre caps respectively. ${ }^{197}$ In addition, the bill creates a new Environmental Quality Incentives Program that provides for cost-sharing and incentive payments for up to seventy-five percent of the cost of conservation practices. ${ }^{198}$ Other environmental provisions include: (1) a modified "Swampbuster" provision that increases a farmer's flexibility by expanding areas for wetlands mitigation; (2) a Wildlife Habitat Incentives Program with cost-sharing for landowners who develop habitat for wildlife, endangered species, and fisheries; and (3) a new conservation program

safety net.) Regardless, keeping permanent law in the legislation acts as a hammer provision forcing Congress to consider new farm policies in 2002 when the 1996 law expires or face reverting back to the 1949 law that is considered economically infeasible. See James Bovard, The 1996 Farm Bill Fiasco?, WALL ST. J., Feb. 6, 1996, at A14. (Bovard points out that Republicans have failed to communicate the real costs of farm programs to the American people. Since President Reagan proposed to eliminate farm programs in 1985, taxpayers have paid more than $\$ 370$ billion for subsidy programs to farmers-an equal sum could have bought all of the farmland in 41 of the states. Furthermore, the Clinton administration rejects the Republican attempt to eradicate government control of farming, arguing for the "preservation of a responsible safety net for farmers," but this is "ludicrous" because the largest percentage of subsidies go to very large farmers and agribusinesses who are wealthier than most other Americans. The average full-time farmer has a net worth of more than $\$ 1$ million according to the Department of Agriculture.)

194. See Bovard, supra note 193; Bruce Ingersoll, Farm Bill Ending Some Crop Limits, Biggest Subsidy Efforts Moves Forward, WALL ST. J., Mar. 22, 1996, at A3.

195. John Merline, Can Farming Survive Markets? Government 'Help' May Do More Harm Than Good, INVESTORS Bus. DAILY, Mar. 9, 1995.

196. Id.

197. Federal Agriculture Improvement and Reform Act of 1996, Pub. L. No. 104-127, $\S \S 332-333,110$ Stat. 888 (1996).

198. Id. $\S 334$. 
offering technical and educational assistance for private grazing landowners. ${ }^{199}$

\section{CONCLUSION}

As we move into the next century, it has become apparent that many forces will shape the changes to come in American agricultural policies. A redoubling of the world's population coupled with increases in Third World incomes will readily increase the demand for food and improved diets. The strain on the earth's resources and added pressure to increase environmental protection both in America and around the world will likely put further limitations on the American farmer's capacity to produce food. These limitations are already being realized in Asia, Africa, and Latin America, the regions whose populations will increase the most despite rapidly declining fertility rates. We now know that despite significant efforts from the United Nations, one-fifth of the world's people, most of whom are in these developing regions, are going hungry every day, and many thousands die because of malnutrition. The increased food production over the last fifty years has occurred arguably at the expense of the world's natural resources. Cropland has been expanded at the expense of tropical rainforests, arid soils have been over irrigated to the point of salination, and aquifers and wetlands are being drained threatening many species of wildlife. Deserts are expanding at alarming rates, and the residue from the intensified use of farm chemicals threaten groundwater supplies and food quality. We know that the world, in which the United States is the leading exporter, has to triple its agricultural output over the next half century. We also know that poor countries will be forced to develop more through trade rather than through aid, especially as budget deficits within the United States constrict foreign aid policies, and we know that in spite of nearly fifty years of human rights development, the right to food has little, if any, meaning as a justiciable right, though some impact as a moral obligation. Last, we now know that the world has no food surplus.

The United States, with much of the world's safest and most suitable cropland, the best infrastructure, research facilities, and temperate climate, must recognize that it is at a defining moment. Perhaps the greatest challenge of the next century is for agriculture to increase production to meet the coming surge in demand primarily on land already devoted or available for that use and in a way that demonstrates environmental stewardship. The only way that U.S. farmers will rise to that challenge is to break down the international trade barriers and eliminate Federal farm micro-management through policies that inhibit production and economic growth. We need to 
eliminate all supply-control programs and let the market correct itself, allow our farmers to unleash expansive land resources, and send a message to the world that American farmers can provide without policies that limit production for export, artificially inflate prices, and undermine our ability to compete abroad. We need to eliminate all of the target-price-fixing by Congress as well as the associated direct or deficiency payments and let market forces dictate the incentives for production and risk-management. If food costs increase, American consumers can afford to pay more for their high dietary standards, although arguably eliminating price supports could effectively lower market prices. For example, eliminating the governmentcontrolled surplus in the "Farmer Owned Reserve" that has been dumped on the market in the past to artificially lower grain prices would remove the anxiety of unpredictable government control of the market through surplus management. Further, we need to eliminate the EEP because it discourages farmers from producing to compete overseas by distorting and depressing the world market price when the Federal government dumps grain on the world market for the benefit of foreign buyers at the expense of American farmers, manufacturers, and consumers. Eliminating many of these programs would effectively reduce the tax burden and help end the budget crisis. A huge USDA bureaucracy could be reduced and restructured and the opportunities for corruption minimized; the inequity of distributing over a quarter of the current federal subsidies to the top two percent of producers would end. We do not need or want a government that guarantees a farmer's success or failure; we want a guarantee that we can compete in a free market. Finally, as the recognized leader of First World capitalism, we need to pressure other countries through GATT and similar multilateral treaties to liberalize trade and reduce subsidies to allow for the economic and ecological rebalancing that the developing world and the degraded earth desperately need.

As a major shift away from the status quo, the 1996 farm legislation, FAIR, is only a gesture toward the kind of radical change justified by what American farmers need in terms of financial security and what the world is depending upon in terms of food security and environmental improvements. If Congress can muster the political will, stop the disingenuous attempts to get the federal government out of farming, recognize the inequities that they have created, and continue to foster the sense of urgency to eliminate cropland set asides and all subsidies, including transition payments, then 
American farmers have a chance to truly experience a golden age-a future with hope for the utopia of a new world order in which a global family of ten billion people can be fed and for a planet that needs to be healed.

Terrence J. Sorg*

* J. D. Candidate, 1997, Indiana University School of Law - Indianapolis; B.A. Architecture; B.S. Environmental Design, 1986 Ball State University. The author dedicates this work to his parents, Thomas $\mathbf{H}$. and Mary $\mathbf{M}$. Sorg for many years of guidance and support. The author especially thanks his wife, Janet, for her endurance and understanding throughout this project. 